\title{
Review Article \\ Review: Biofunctionalized Quantum Dots in Biology and Medicine
}

\author{
Sonal Mazumder, ${ }^{1}$ Rajib Dey, ${ }^{2}$ M. K. Mitra, ${ }^{2}$ S. Mukherjee, ${ }^{2}$ and G. C. Das ${ }^{2}$ \\ ${ }^{1}$ Department of Engineering Science Mechanics, Virginia Polytechnic Institute and State University, Blacksburg, VA 24061, USA \\ ${ }^{2}$ Department of Metallurgical and Material Engineering, Jadavpur University, Kolkata 700032, India
}

Correspondence should be addressed to Rajib Dey, rajib.dey@gmail.com

Received 18 June 2009; Accepted 2 August 2009

Recommended by Kui Yu

Quantum dot (QD) nanocrystals which have important optical properties, in particular, the wavelength of their fluorescence, depend strongly on their size. Colloidal QDs once dispersed in a solvent are quite interesting fluorescence probes for all types of labelling studies because of their reduced tendency to photo bleach. In this review, we will give an overview on how QDs have been used so far in cell biology. In particular, we will discuss the biologically relevant properties of QDs and focus on four topics: labeling of cellular structures and receptors with QDs, incorporation of QDs by living cells, tracking the path and the fate of individual cells using QD labels, and QDs as contrast agents. QDs are seen to be much better in terms of efficacy over radioisotopes in tracing medicine in vivo. They are rapidly being applied to existing and emerging technologies but here this review deals with a comprehensive compilation of the biological relevance of quantum dots. It covers important information from 1999 till 2008 with few from 1982 to 1997.

Copyright (C) 2009 Sonal Mazumder et al. This is an open access article distributed under the Creative Commons Attribution License, which permits unrestricted use, distribution, and reproduction in any medium, provided the original work is properly cited.

\section{Introduction}

1.1. Definition of Quantum Dots. QDs are highly crystalline molecular sized semiconductor nanocrystals. These are made up of 100-100 000 number of atoms. Due to their reduced size, they have discrete electronic energy that gives rise to unique optical properties. They have rapidly emerged as a new class of fluorescent probes for biomolecular and cellular imaging.

1.2. Role of Quantum Dots. These unique properties of QDs have improved the sensitivity of molecular imaging and quantitative cellular analysis by 1-2 orders of magnitude. Recent advances have led to multifunctional nanoparticle probes which are highly bright and stable under complex in-vivo conditions. The novel properties of QDs arise from quantum size confinement, which was first reported by Ekimov and Onushchenko in 1982 when they observed sharp and discrete absorption peaks in $\mathrm{CuCl}$ nanocrystals embedded in a transparent insulating matrix [1]. About 10 years later procedures for synthesis of high-quality CdSe QDs dispersed in organic solvents were developed by
Murray et al. [2]. However, it was not until 1998 that QDs entered into their new role as fluorescent probes when two groups simultaneously reported the procedures for making QDs water-soluble and conjugating them to bimolecules $[3,4]$. Following these reports, extensive research has been directed toward developing QDs for use in biodetection and bioimaging. The dimensional similarities between these quantum dots and biological macromolecules could allow an integration of nanotechnology with biology, leading to various advantages in medical science, molecular biology, and cell biology (Figure 1 depicts probable applications of QDs in the future). In particular, high-quality QDs have been made water-soluble by coating them with ampliphilic polymers or by ligand exchange $[5,6]$. Water-soluble QDs have also been linked to small proteins $[6,7]$, peptides $[8]$, nucleic acids [9], carbohydrates [10,11], polymers [8], and other small molecules [12].

1.3. Quantum Dots Not Fluorophores. Many of the organic dye and protein-based fluorophores (materials which fluorescence on excitation with light) currently in use suffer from serious chemical and photophysical liabilities. These 


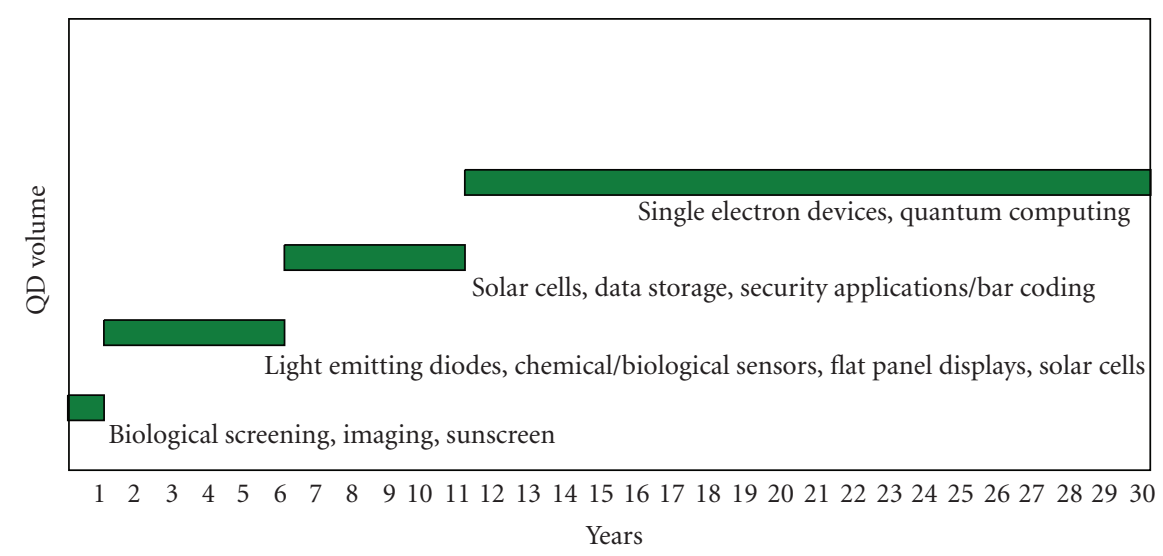

FIgure 1: Present and Future Application of QDs. (Nanoco Technologies Limited).

include $\mathrm{pH}$ dependence, self-quenching at high concentrations, susceptibility to photo-bleaching, short-term aqueous stability, narrow absorption windows coupled to broad redtailed emission spectra via small Stokes shifts, and short excited state fluorescent lifetimes $[13,14]$.

In comparison with the organic dyes and fluorescent proteins, QDs have unique optical and electronic properties size tunable light emission, improved signal brightness, resistance against photobleaching and simultaneous excitation of multiple fluorescence colours. Using bioconjugated (Bioconjugation is the process of coupling two biomolecules together in a covalent linkage), QDs as fluorescent probes, recent research has achieved real-time imaging of single cell surface receptors [15] and noninvasive detection of small tumors in live animal models [16]. They have found widespread use in myriad biosensing applications including immunoassays, nucleic acid detection, resonance energy transfer studies, clinical/diagnostic assays, and cellular labeling, $[13,14,17]$. Over time, this has resulted in the synthesis of a vast library of fluorophores, many of which are geared toward very specific applications. Since their first description in a biological context $[3,18]$, colloidal luminescent semiconductor nanocrystals, or quantum dots (QDs) have elicited a great deal of interest in the biosensing community due to their unique fluorescent properties. Cumulatively, these fluorescent properties may overcome some of the liabilities of conventional organic and proteinbased fluorophores to help create a new generation of robust biosensors. Here we examine the progress in adapting QDs for various biosensing applications. For the purposes of this review we define biosensing loosely as the utilization of biomolecular specificity to detect and/or quantitate other molecules (which may or may not be of biological origin). This is distinct from using QDs to label/track cells or for invivo imaging, recently reviewed in references [19-26].

1.4. Synthesis of QDs. Till now CdSe/ZnS core/shell QDs remain among the best available for almost all biological applications [21, 22, 27-29]. Highly crystalline, narrowly dispersed CdSe QDs can be synthesized at high temperatures using a mixture of organometallic precursors and trioctyl phosphine/trioctyl phosphine oxide (TOP/TOPO) growth solvent/ligands [2]. CdSe core was over coated with a layer of wider bandgap semiconductor such as ZnS and CdS [28,30]. This secondary layer passivates the surface and increases the photoluminescent yield [30-32]. Other QDs including ZnS, $\mathrm{ZnSe}, \mathrm{PbS}, \mathrm{CdS}, \mathrm{CdTe}$, and $\mathrm{PbSe}$ with emissions ranging from the UV to the IR have also been synthesized, however these are not as common in biological assays [21, 22, 28, 29, 33]. In a recent review, Michalet provided an excellent overview of the correlation between several constituent QD materials, their core size, and their emission maxima [8].

\section{Functionalization of QDs: Solubilization and Bioconjugation}

2.1. Requirement of Functionalization. Most of the synthesis methods that produce highly monodisperse, homogeneous nanoparticles use organic solvents. The particles that are produced need to be rendered water soluble for biological applications. They need to be biofunctionalized in order to meet four four key requirements: $[14,34]$

(1) increased stability in water for long period,

(2) presence of sterically accessible functional groups for bioconjugation,

(3) biocompatibility and non immunogenecity in living systems,

(4) lack of interference with the nanoparticles native properties.

Following Figure 2 represents schematically the biological labeling by QDs.

2.2. Solubilization. Semiconductor QDs can be solubilized by several methods. A very common method is the ligand exchange method in which the surface ligands are exchanged with a thiol group such a mercapto-acetic acid [3] or polysilanes [4]. Another method includes a hydrophobic interaction between tri-n-octylphosphine oxide and an amphiphilic polymer Apart from these two other water solubilization procedures such as encapsulation in phospolipid micelled 

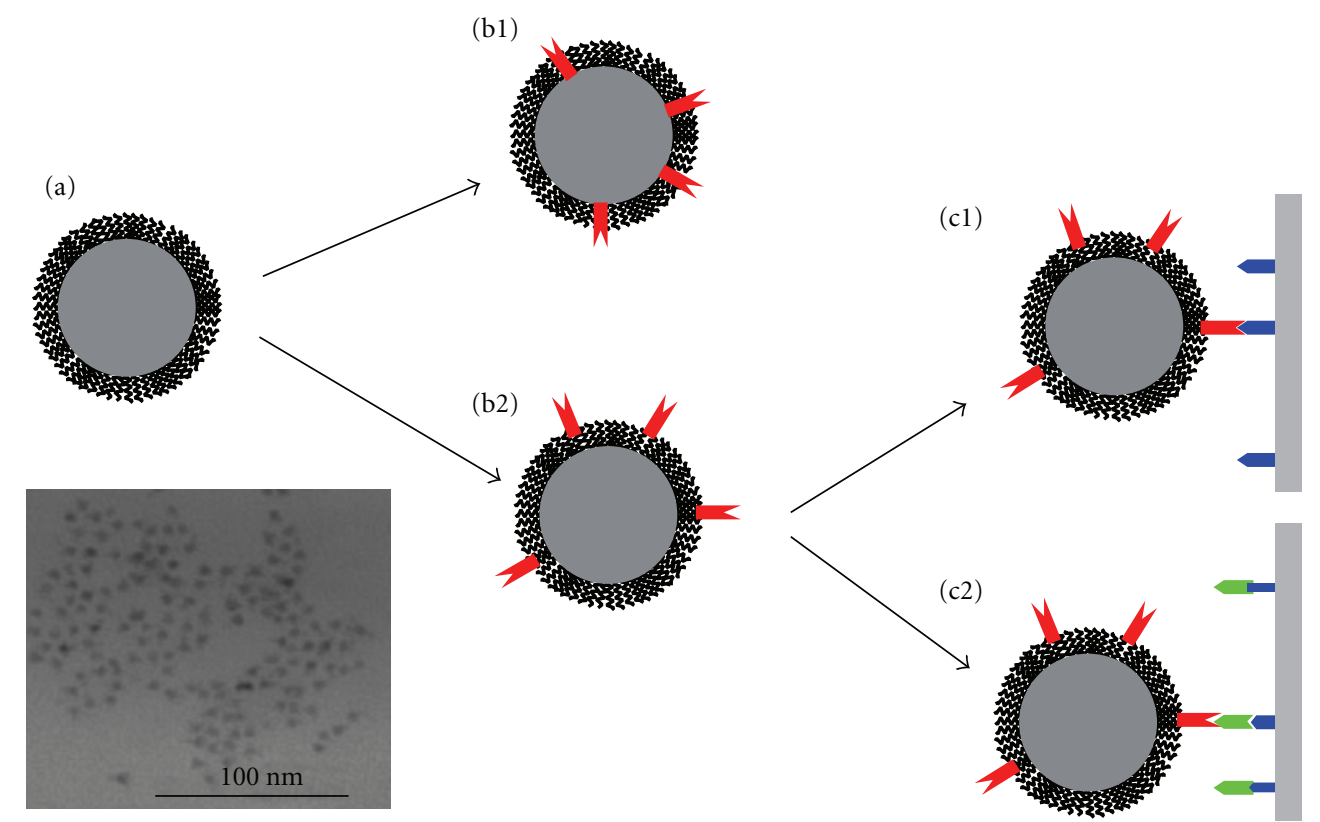

FIGURE 2: Schematic representation of the use of colloidal QDs for biological labelling. (a)Water-soluble QDs comprise a semiconducting core (drawn in grey) and a hydrophilic shell (drawn in black). (b) In order to specifically label biological structures water-soluble QDs have to be conjugated with biological molecules (drawn in red) such as antibodies. The biological molecules can be either adsorbed (b1) to the semiconducting core or bound to the hydrophilic shell (b2). (c) Bioconjugated QDs bind specifically to designated receptors. In (c1) the ligand (e.g., a primary antibody, drawn in red) bound to the quantum dot directly recognizes specific receptor molecules (drawn in blue). In (c2) the receptor (drawn in blue) is first labelled by a primary ligand (e.g., primary antibody, drawn in green), which in turn is recognized by the ligand (e.g., a secondary antibody, drawn in red) bound to the QD. Inset: red fluorescent CdSe/ZnS quantum dots have been made water soluble by coating them with an amphiphilic polymer. The image shows a transmission electron micrograph (TEM) of some of these quantum dots adsorbed on a TEM grid [24].

$[35,36]$ or coating the nanoparticle with a polysaccharide layer [36] mainly in case of magnetic nanoparticles are also in use. The following examples are presented to make the idea more clear.

Example 1. The most common synthesis of semiconductor nanocrystals such as $\mathrm{CdS}$, CdSe, CdTe, or $\mathrm{CdSe} / \mathrm{ZnS}$ is carried out in organic solvents at high temperatures in the presence of surfactants to yield monodisperse and stable particles. This leads to the production of surfactant-coated particles. Here the polar surfactant head group is attached to the inorganic surface, the hydrophobic chain protruding into the organic solvent, mediating colloidal stability. The solvents, which are used for the dispersion of these particles are toluene or chloroform, but because of their hydrophobic surface layer they are not soluble in aqueous media. However, almost all experiments involving cells require water-soluble materials. Thus the surfactant layer is replaced or a coating is done with an additional layer introducing either electric charge or hydrophilic polymers for mediating solubility in water. Coulomb repulsion between nanocrystals with surface charge of the same polarity prevents aggregation in water.

Example 2. In practice, hydrophobic nanocrystals can be made hydrophilic by several methods. Most of them rely on the exchange of the hydrophobic surfactant coatings with ligand molecules that carry on one end functional groups that are reactive towards the nanocrystal surface, and hydrophilic groups on the other end, which ensure water solubility. The most frequently used hydrophilic head groups reactive to the surface of semiconductor nanocrystals are thiol $(-\mathrm{SH})$ functionalities and carboxyl $(-\mathrm{COOH})$ functionalities. The source of these groups such as mercaptohydrocarbonic acids $(\mathrm{SH}-\cdots-\mathrm{COOH})$ are mercaptoacetic acid $[3,38-$ 40], mercaptopropionic acid [41], mercaptoundecanoic acid [42], mercaptobenzoic acid [43], dihydrolipoic acid [44], and cysteine $[45,46]$. Synthetic peptides with multiple cysteines have been used by Pinaud et al. as the anchor [47]. Also noncharged molecules like dithiothreitol [48], organic dendrons [49], and pyridine-functionalized polyethylene glycol (PEG) [50] have been attached to the semiconductor surface and three methoxy groups are exposed to the solvent. Another approach involves growth of hydrophilic silica shells around nanocrystals $[19,51-54]$. In Figure 4 quantum dots (QDs) are coupled to G-protein coupling receptors (GPCRs) [37]. Here diblock copolymer with acrylic acids are used as hydrophilic segments and amido-octyl side chains as hydrophobic segments for facile encapsulation of QDs. GPCRs are proteins which transduce extracellular stimuli into intracellular signals.

2.3. Bioconjugation. In order to apply QDs in various biological systems, certain biological molecules can be attached to the surface of these dots without any damage to the 


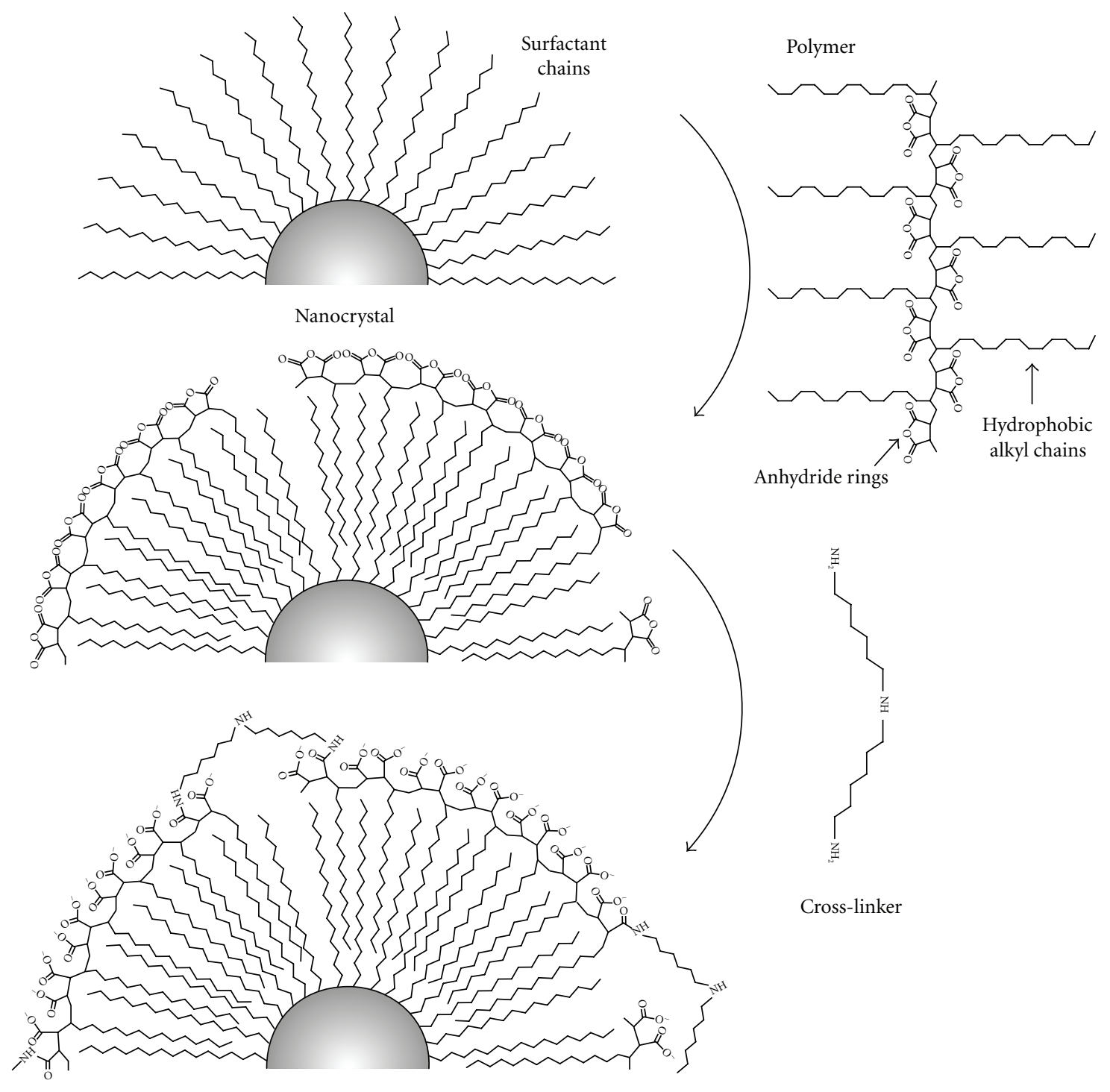

FIGURE 3: Scheme of the polymer coating procedure. Several reports suggest that the surfactant chains for hydrophobically capped nanocrystals are pointing away from the nanocrystal surface, in a brush-like arrangement. The following plausible configuration is then assumed for the polymer (Poly(maleic anhydride-alt-1-octadecene)) coating process: the hydrophobic alkyl chains of the polymer intercalate with the surfactant coating. The anhydride rings are located on the surface of the polymer-coated nanocrystal. The amino end groups of the cross-linker molecule open the rings and link the individual polymer chains. The surface of the polymer shell becomes negatively charged, stabilizing the particles in water by electrostatic repulsion.

properties of the molecules [55]. These Biological molecules are attached to the quantum dots by means of cross-linker molecules [37, 42-54] by hydrophilic surfactant shells with reactive groups, such as $-\mathrm{COOH},-\mathrm{NH}_{2}$, or $-\mathrm{SH}$. The attachments successfully takes place by different approaches like adsorption, covalent linkage, electrostatic interaction, and so forth. Thiols $(-\mathrm{SH})$ bond of mercapto group bind to the surface of the most often used semiconductor materials (CdSe, CdS, CdTe, $\mathrm{ZnS}$ ) and therefore quantum dots can be conjugated to biological molecules bearing mercapto $(-\mathrm{SH})$ groups in this way [56, 57]. Also oligonucleotides [42, 43] and various serum albumins [18], are readily adsorbed to the surface of watersoluble QDs. This adsorption depends on ionic strength, $\mathrm{pH}$, temperature, and the surface charge of the molecule. It was seen that the protein conjugated QDs had higher fluroscent yield from that of the non-conjugated QDs [58].

Various cross-linker such as 1-ethyl-3- (3-dimethylaminopropyl) carbodiimide (EDC) is commonly used to link $-\mathrm{NH}_{2}$ and $-\mathrm{COOH}$ groups, whereas 4 -(N-maleimidomethyl)-cyclohexanecarboxylic acid N-hydroxysuccinimide ester (SMCC) can be used to cross-link $-\mathrm{SH}$ and $-\mathrm{NH}_{2}$ groups [59]. Using the above methods, there have been numerous reports of conjugating QDs with various biological 

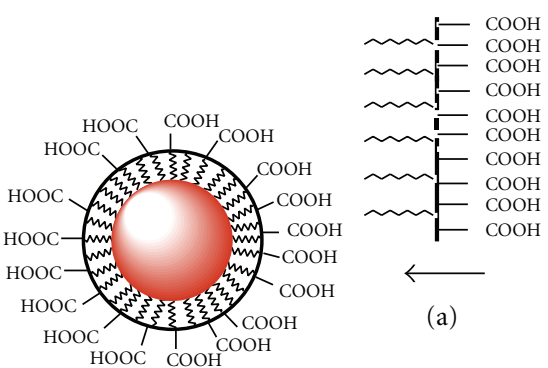

(a)

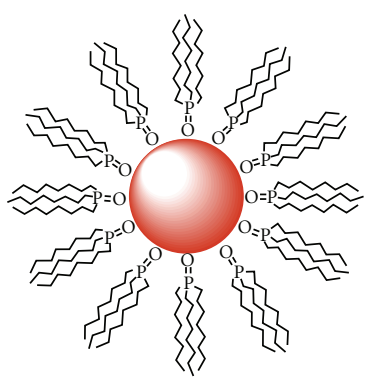

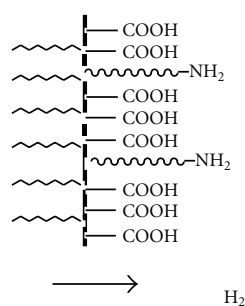

(b)

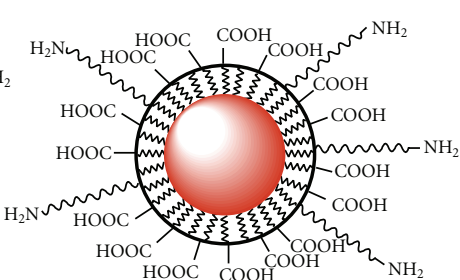

(1)

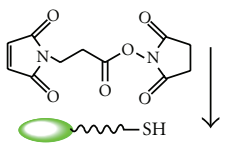

(2)

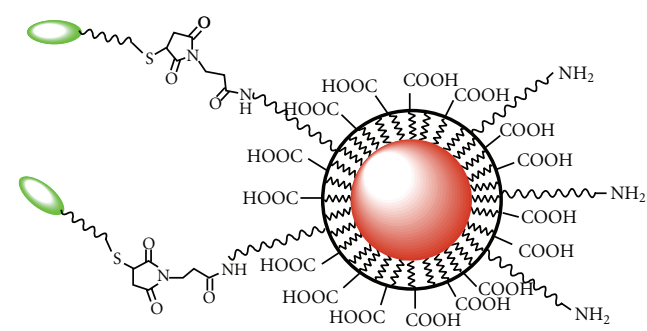

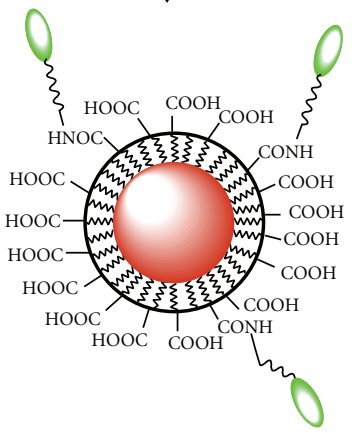

Quantum dots

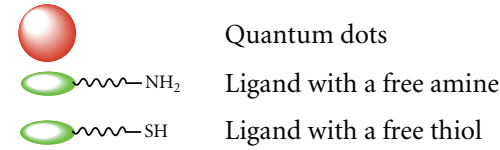

FIGURE 4: Synthesis of water-soluble QDs with associated ligand conjugation chemistry. (a) Carboxylic acid functionalized QDs for conjugation to ligands through EDAC coupling. (b) Amine-functionalized QDs for conjugation to thiol-containing ligands through bifunctional cross-linkers [37].

molecules, including biotin, peptides [60]; and proteins, including avidin/streptavidin [61], albumin [62], and antibodies [63].

With the broad range of bioconjugation methods available [64] it is now possible to conjugate nanoparticles with ligands, peptides, carbohydrates, nucleic acid, protein, lipids, and polymers. Probe design also plays a critical role when the probes are used in biological solution, inside cells or in-vivo. However the probes are required to be delivered to the site of the target [refer to Figure 5]. Frequently, it is observed that the biological functions of these conjugated molecules have not been affected by linkage to QDs in most cases.

Example 3. A naturally based biopolymer obtained by the alkaline deacetylation of chitin is chitosan, which is hydrophilic, nontoxic, biocompatible, and biodegradable. Hence, it has been extensively investigated as a carrier for a wide range of drug delivery applications. The most widely used method for synthesizing chitosan nanoparticles is based on ionic gelation using sodium tripolyphosphate as a counterion. However, it usually yields large polydisperse chitosan nanoparticles. Furthermore, the biodistribution of chitosan nanoparticles and the mechanism of their delivery to cells and tissues remain unclear. It is noted that chitosan molecules contain amino groups, which can be used as active reaction sites to be linked to the carboxylicfunctionalized QDs. Thus the chitosan/QD nanoparticles developed, various in vitro and in vivo imaging techniques can be used to study the biodistribution of nanoparticles and their intracellular pathways, and the same results can be used for the delivery of drugs, genes, and other biomolecules, using chitosan as a carrier $[84,88]$.

Table 1 represents the bioconjugation of QD with different biolinkers and biomolecules necessary for different sensing applications.

2.4. Different Problems Associated with Biofunctionalization. Biological molecules can be conjugated to colloidal QDs as described above. For potential applications it is important to know if the functionality of the molecules is retained or whether it is impaired by the quantum dot. Since colloidal QDs have the size of a few nanometers, the attachment of such objects to a biological molecule might well influence its properties, for example, in terms of steric hindrance. As for example that the conjugation of single-stranded oligonucleotides to the surface of gold nanoparticles reduces hybridization capacity with complementary oligonucleotides 
TABLE 1: Biofunctionalised Quantum dots used for different applications (refer [3, 23, 65-83]).

\begin{tabular}{|c|c|c|c|c|c|}
\hline SL number & Biolinkers & $\begin{array}{l}\text { Biomolecules } \\
\text { attached }\end{array}$ & $\begin{array}{l}\text { Quantum } \\
\text { dots }\end{array}$ & $\begin{array}{l}\text { Applications as } \\
\text { biosensor }\end{array}$ & References \\
\hline 1 & $\begin{array}{l}\text { TOPO (trioctyl } \\
\text { phosphine oxide) along } \\
\text { with MAA (Mercapta } \\
\text { Acetic acid) }\end{array}$ & Glycoproteins & CdSe & $\begin{array}{l}\text { Label } \\
\text { microorganisms } \\
\text { and label specific } \\
\text { cell type and } \\
\text { lineages in in vitro } \\
\text { system }\end{array}$ & {$[66]$} \\
\hline 2 & $\begin{array}{l}\text { TOPO (trioctyl } \\
\text { phosphine oxide) }\end{array}$ & Transferrin & CdSe & $\begin{array}{l}\text { Identifying } \\
\text { bacteria and } \\
\text { biochemical } \\
\text { process of bacteria } \\
\text { iron acquisition }\end{array}$ & {$[67]$} \\
\hline 3 & $\begin{array}{l}\text { Primary-amine- } \\
\text { containing molecules } \\
\text { using the activator EDC } \\
\text { (1-ethyl-3-(3- } \\
\text { dimethylaminopropyl) } \\
\text { carbodiimide } \\
\text { hydrochloride) }\end{array}$ & Adenine and AMP & $\begin{array}{l}\mathrm{CdSe} / \mathrm{CdSe}- \\
\mathrm{ZnS}\end{array}$ & $\begin{array}{l}\text { Labeling bacteria } \\
\text { by Purine } \\
\text { dependent } \\
\text { mechanisms }\end{array}$ & {$[67]$} \\
\hline 4 & $\begin{array}{l}\text { TOPO (trioctyl } \\
\text { phosphine oxide) along } \\
\text { with MES } \\
\text { (Mercaptoethane } \\
\text { Sulphonate) }\end{array}$ & * & CdSe & $\begin{array}{l}\text { Determination of } \\
\text { free cyanide in } \\
\text { aqueous solution } \\
\text { with high } \\
\text { sensitivity }\end{array}$ & {$[69]$} \\
\hline 5 & $\begin{array}{l}\text { Polystyrene } \\
\text { microspheres }\end{array}$ & Rabbit IgG & $\mathrm{CdTe}$ & $\begin{array}{l}\text { Detection of fluo- } \\
\text { romicrospheres in } \\
\text { laser induced } \\
\text { fluorescent systems }\end{array}$ & {$[70]$} \\
\hline 6 & Protein transferrin & HeLa Cells & $\begin{array}{l}\text { ZnS capped } \\
\text { Cadmium } \\
\text { Selenide }\end{array}$ & $\begin{array}{l}\text { Ultrasensitive non } \\
\text { isotopic detection }\end{array}$ & {$[3]$} \\
\hline 7 & Chitosan polymer & * & $\begin{array}{l}\text { Manganese } \\
\text { doped Zinc } \\
\text { Sulphide QD }\end{array}$ & $\begin{array}{l}\text { Detection of } \\
\text { bacillus bacteria }\end{array}$ & {$[66,71]$} \\
\hline 8 & $\begin{array}{l}\text { Suitable ampiphilic } \\
\text { Polymer }\end{array}$ & streptavidin & CdSe/ZnS & $\begin{array}{l}\text { Detection of E. } \\
\text { Coli O157:H7 cells }\end{array}$ & {$[72]$} \\
\hline 9 & PEG polymer & $\begin{array}{l}\text { GFE, F3, Lyp-1 } \\
\text { peptide }\end{array}$ & $\begin{array}{l}\text { ZnS capped } \\
\text { CdSe }\end{array}$ & $\begin{array}{l}\text { Invivo Targeting; } \\
\text { blood vessel and } \\
\text { tumour in mice }\end{array}$ & {$[84]$} \\
\hline 10 & RGD peptide & * & CdSe & $\begin{array}{l}\text { Labeling and } \\
\text { Imaging of Human } \\
\text { Mesenchymal Stem } \\
\text { Cells }\end{array}$ & {$[73]$} \\
\hline 11 & $\begin{array}{l}\text { AFP (alpha-fetoprotein) } \\
\text { antibody }\end{array}$ & Tumour tissue & $\begin{array}{l}\text { ZnS capped } \\
\mathrm{CdSe}\end{array}$ & $\begin{array}{l}\text { Hepatic Cancer } \\
\text { detection }\end{array}$ & {$[68]$} \\
\hline 12 & Avidin & Antibody & $\begin{array}{l}\text { CdSe-ZnS } \\
\text { core }\end{array}$ & $\begin{array}{l}\text { Detection of } \\
\text { Cholera toxin and } \\
\text { SEB }\end{array}$ & {$[84]$} \\
\hline 13 & TCS (Tricosanthin) & $\begin{array}{l}\text { Human } \\
\text { choriocarcinoma } \\
\text { cells (JAR cells) }\end{array}$ & $\begin{array}{l}\text { ZnS capped } \\
\text { CdSe }\end{array}$ & Treatment of AIDs & {$[85]$} \\
\hline 14 & Streptavidin & $\alpha$ tubulin antibody & $\mathrm{CdSe} / \mathrm{ZnS}$ & $\begin{array}{l}\text { Immunolabelling } \\
\text { of mouse embryo } \\
\text { fibroblast cells }\end{array}$ & {$[23]$} \\
\hline
\end{tabular}


TABle 1: Continued.

\begin{tabular}{|c|c|c|c|c|c|}
\hline SL number & Biolinkers & $\begin{array}{l}\text { Biomolecules } \\
\text { attached }\end{array}$ & $\begin{array}{l}\text { Quantum } \\
\text { dots }\end{array}$ & $\begin{array}{l}\text { Applications as } \\
\text { biosensor }\end{array}$ & References \\
\hline 15 & Streptavidin & biotinylated MAb & $\mathrm{CdSe} / \mathrm{ZnS}$ & $\begin{array}{l}\text { C. parvum oocyst } \\
\text { detectionWater- } \\
\text { borne } \\
\text { pathogen }\end{array}$ & {$[74]$} \\
\hline 16 & Streptavidin & Actinomyosin & CdSe & $\begin{array}{l}\text { Cargo detection } \\
\text { and filament } \\
\text { tracking }\end{array}$ & {$[75]$} \\
\hline 17 & Streptavidin & & CdSe-ZnS & $\begin{array}{l}\text { Human metaphase } \\
\text { chromosomes }\end{array}$ & {$[76]$} \\
\hline 18 & Peptide & Angiotensin & CdSe-ZnS & $\begin{array}{l}\text { image angiotensin } \\
\text { I-expressing } \mathrm{CHO} \\
\text { (Chinese hamster } \\
\text { ovary) cells in vitro }\end{array}$ & {$[77]$} \\
\hline 19 & Phytochelatin peptides & streptavidin & CdSe-ZnS & Cell imaging & {$[86]$} \\
\hline 20 & Streptavidin & DNA & $\begin{array}{l}\text { Gold } \\
\text { Nanopaticle } \\
\end{array}$ & $\begin{array}{l}\text { Detection of } \\
\text { Nucleic acids } \\
\end{array}$ & {$[78]$} \\
\hline 21 & $*$ & DNA & $\mathrm{CdS}$ & DNA labelling & [79] \\
\hline 22 & $\begin{array}{l}\text { OPA copolymer } \\
\text { (oligomer of } \\
\text { amine-terminated } \\
\text { polyaniline) by EDAC } \\
\text { coupling reagent (1-(3- } \\
\text { Dimethylaminopropyl)- } \\
\text { 3-ethylcarbodiimide) }\end{array}$ & Deltrophin-II & CdSe-ZnS & $\begin{array}{l}\text { Labelling GPCRs } \\
\text { (G-protein } \\
\text { coupling receptors) }\end{array}$ & [80] \\
\hline 23 & Thioglycolic acid & Cy3-DNA & CdTe & $\begin{array}{l}\text { Detection of DNA } \\
\text { hybridization }\end{array}$ & [81] \\
\hline 24 & $\begin{array}{l}\text { Teflon-AF LCWs (Liquid } \\
\text { core waveguides) }\end{array}$ & $\begin{array}{l}\text { Alexfluor } \\
\text { 546-labeled IgG } \\
\text { antibody }\end{array}$ & $\begin{array}{l}\text { Catskill green } \\
(\mathrm{CdSe} / \mathrm{ZnS})\end{array}$ & $\begin{array}{l}\text { Detection of cTnI } \\
\text { in PBS (phosphate } \\
\text { buffered saline) } \\
\text { and human } \\
\text { plasma. }\end{array}$ & [87] \\
\hline 25 & 2-aminoethanthiol & $*$ & PbSe & $\begin{array}{l}\text { Biosensor and drug } \\
\text { delivery }\end{array}$ & [82] \\
\hline
\end{tabular}

*indicates that no suitable biolinker or biomolecule is attached to the QDs for those particular application.

[89]. Therefore, preservation of the functionality of the molecule cannot be taken for granted and must be proven experimentally. Functionality of biological molecules can be regarded from different perspectives. Generally QDs in cell biology are their use as fluorescence markers to label structures/compartments/molecules in cells (discussed in Section 2). For this purpose quantum dots are conjugated to ligand molecules (such as antibodies) that recognize specific receptors, that is, the structure/compartment/molecule which is to be labelled. Therefore, it is important that the QDs do not interfere with molecular recognition. These QDs may effect enzymatic action of the biological molecules to catalyze certain reaction and neurotransmitters for opening and blocking channels. Some studies are available at present in which the functionality of biological molecules labeled with colloidal QDs is investigated. Zhang et al. claim that the enzymatic activity of the ribosome-inactivating protein trichosanthin did not change significantly when it was attached to colloidal CdSe/ZnS QDs [38]. Dahan et al. report that labelling of membrane-bound receptors with quantum dots did not have drastic effects on the diffusion behavior of the receptors in membranes [13]. Kloepfer et al. have investigated the effect of QD conjugation on the functionality of the protein transferrin and conclude from three experiments that the protein's function is not compromised by its attachment to QDs [40]. In a detailed study by the Rosenthal group the effect of QD conjugation to the neurotransmitter serotonin was investigated [5]. Their experimental data suggest that conjugation to quantum dots dramatically reduces the binding affinity of serotonin to serotonin-transporter proteins. Moreover, for Xenopus oocytes expressing ionotropic serotonin receptors a serotonin-induced inward current was recorded for perfusion with free serotonin, but no current was observed in 

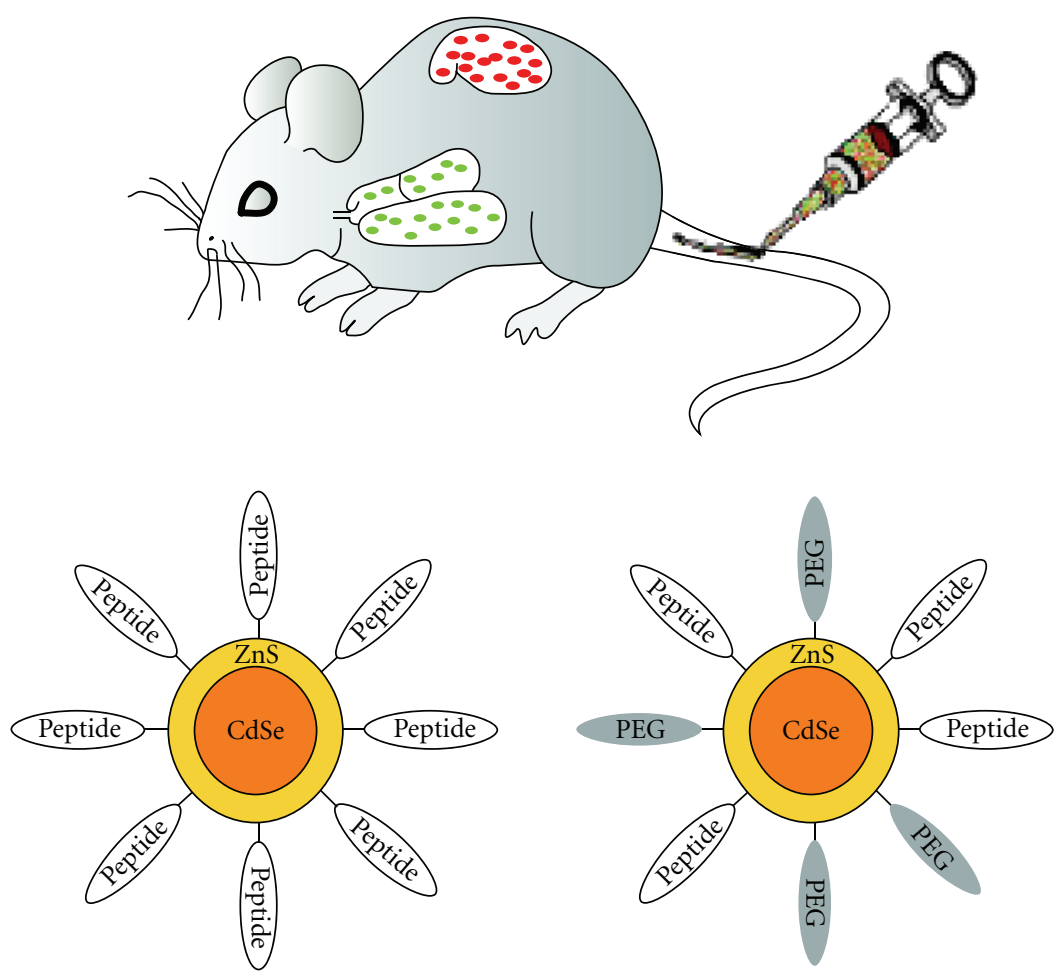

FIGURE 5: Schematic representation of QD targeting. Intravenous delivery of QD into specific tissues of the mouse. (Upper) Design of peptide coated QD. (Lower) QD were coated with either peptides only or with peptides and PEG.PEG helps the QD to maintain solubility in aqueous solvents and minimize nonspecific binding [65].

the case of perfusion with serotonin-QD conjugates. The experiments from the Rosenthal group clearly demonstrate that the conjugation of biological molecules to quantum dots can impair their functionality. However, to our knowledge there are no detailed studies available at present in which the functionality of molecules conjugated to QDs is analysed in a quantitative way, for example, in terms of binding constants or catalytic activity.

\section{Novel Properties}

Conventional organic fluorophores suffer from poor photostability, narrow absorption spectra and broad emission spectra. Table 2 presents an overview of several QD properties as compared to those of organic and protein based fluorophores [90].

Semiconductor nanocrystals, however, are highly photostable with broad absorption spectra and narrow sizetunable emission spectra. Recent advances in the synthesis of these materials have resulted in the generation of bright, sensitive, extremely photo-stable and biocompatible semiconductor fluorophores. QDs also have other unique electronic properties. The size and shape of their structures and therefore the number of electrons they contain, can be precisely controlled; a QD can have anything from a single electron to a collection of several thousands electrons.

Commercial availability facilitates their application in a variety of unprecedented biological experiments, including multiplexed cellular imaging, long-term in vitro and in vivo labeling, deep tissue structure mapping and single particle investigation of dynamic cellular processes.

The energy levels of quantum dots are discrete rather than continuous. It affects a few properties as the following.

(i) The addition or subtraction of just a few atoms to the QD has the effect of altering the boundaries of the bandgap.

(ii) Changing the geometry of the surface of the QD also changes the bandgap energy, owing again to the small size of the dot, and the effects of quantum confinement. The bandgap in a quantum dot will always be energetically larger; therefore, we refer to the radiation from quantum dots to be "blue shifted" reflecting the fact that electrons must undergo jump from one energy level to another of greater energy difference and thus produce radiation of a shorter and therefore "bluer" wavelength. As with bulk semiconductor material, electrons tend to make transitions near the edges of the bandgap. However, with quantum dots, simply adjusting the size of the dot controls the size of the bandgap. Because the emission frequency of a dot is dependent on the bandgap, it is therefore possible to control the output wavelength of a dot with extreme precision.

(iii) QDs have large molar extinction coefficients in the order of $5.5 \times 10^{6} \mathrm{M}^{-1} \mathrm{~cm}^{-1}[91]$. 
TABLE 2: Comparison of properties of Fluoropores and QDs.

\begin{tabular}{|c|c|c|}
\hline Property & Fluoropores & Quantum Dots \\
\hline Absorption spectra & $\begin{array}{l}\text { Variable/narrow generally a } \\
\text { mirror of the emission } \\
\text { spectra }\end{array}$ & $\begin{array}{l}\text { Broad spectra, steadily increases towards the } \\
\text { UV from the first absorption band edge }\end{array}$ \\
\hline Maturation time & $\begin{array}{l}\text { Needed for fluorescent } \\
\text { proteins }\end{array}$ & NA \\
\hline Molar extinction coefficients & $\begin{array}{l}\text { Variable, Generally } \\
<200,000 \mathrm{M}^{-1} \mathrm{~cm}^{-1}\end{array}$ & High, 10-100X that of fluorophores \\
\hline Fluorescent lifetime & Short $<5 \mathrm{~ns}$ & Long $\sim 10-20$ ns or greater \\
\hline Spectral range & $\begin{array}{l}\text { Necessitates a different dye } \\
\text { every } 40-60 \mathrm{~nm}\end{array}$ & $\begin{array}{l}\text { UV-IR depending upon binary/ternary } \\
\text { materialVis-CdSe }\end{array}$ \\
\hline Tunable emission & NA & $\begin{array}{l}\text { Unique to QDs / can be size-tuned from the } \\
\text { UV to IR }\end{array}$ \\
\hline Multiplexing capabilities & Rare & Excellent, largely unexplored \\
\hline Intermittency (blinking) & Negligible & $\begin{array}{l}\text { Maybe problematic in isolated } \\
\text { circumstances (single molecule tracking) }\end{array}$ \\
\hline Quantum yield & Variable, low to high & $\begin{array}{l}\text { Generally high, } 0.2 \text { to } 0.7 \text { in buffer } \\
\text { depending upon surface coating }\end{array}$ \\
\hline Photostability & Variable to poor & $\begin{array}{l}\text { Excellent, strong resistance to } \\
\text { photobleaching several orders of magnitude } \\
\text { that of dyes multiple acceptor } \\
\text { configurations possible }\end{array}$ \\
\hline Multiphoton cross section & Variable to poor & $\begin{array}{l}\text { Excellent }>2-3 \text { orders of magnitude that of } \\
\text { dyes }\end{array}$ \\
\hline Emission spectra Effective Stokes shifts & $\begin{array}{l}\text { Broad, asymmetric } \\
\text { red-tailed emission }\end{array}$ & $\begin{array}{l}\text { Narrow-full width at half-maximum } \\
25-40 \mathrm{~nm} \text { for CdSe core materials }\end{array}$ \\
\hline Chemical resistance & variable & Excellent \\
\hline Reactivity & $\begin{array}{l}\text { Multiple relativities } \\
\text { commercially available }\end{array}$ & Limited conjugation chemistries available \\
\hline Mono-valent attachment & Easy & Difficult \\
\hline Multi-valent attachment & Rare-mostly bis-functional & $\begin{array}{l}\text { Good possibilities, can attach several } \\
\text { molecules to QDs depending upon size }\end{array}$ \\
\hline Physical size & $<0.5 \mathrm{~nm}$ & $4-7 \mathrm{~nm}$ diameter for CdSe core material \\
\hline Cost effectiveness & $\begin{array}{l}\text { Very good/multiple } \\
\text { suppliers }\end{array}$ & Poor/2 commercial suppliers \\
\hline Electrochromicity & Rare & Largely untapped \\
\hline
\end{tabular}

(iv) Absorption rate is $10-50$ times faster than organic dyes.

(v) QDs are 10-20 times brighter than organic dyes.

(vi) The longer excited state lifetime of QDs provide a means for separating the QD fluorescence from background fluroscence through a technique known as time-domain imaging.

(vii) Size and composition tunable fluorescence emission from vis-infrared wavelength. One light source can be used to excite multiple colors of fluorescence emission. (viii) Very large stokes spectral shifts. Stokes shifts of semiconductor QDs can be as large as 300-400 nm.

(ix) Can be used image and track multiple molecular targets simultaneously.

QDs will fluoresce or stay lit much longer than dyes conventionally used for tagging cells. They are showing promise in early warning test kits for disease. Dots are tagged to proteins and their glow enables the identification of specific proteins or DNA making it possible to diagnose various diseases. How much protein is on each cell can be ascertained by the amount of light transmitted in a particular 


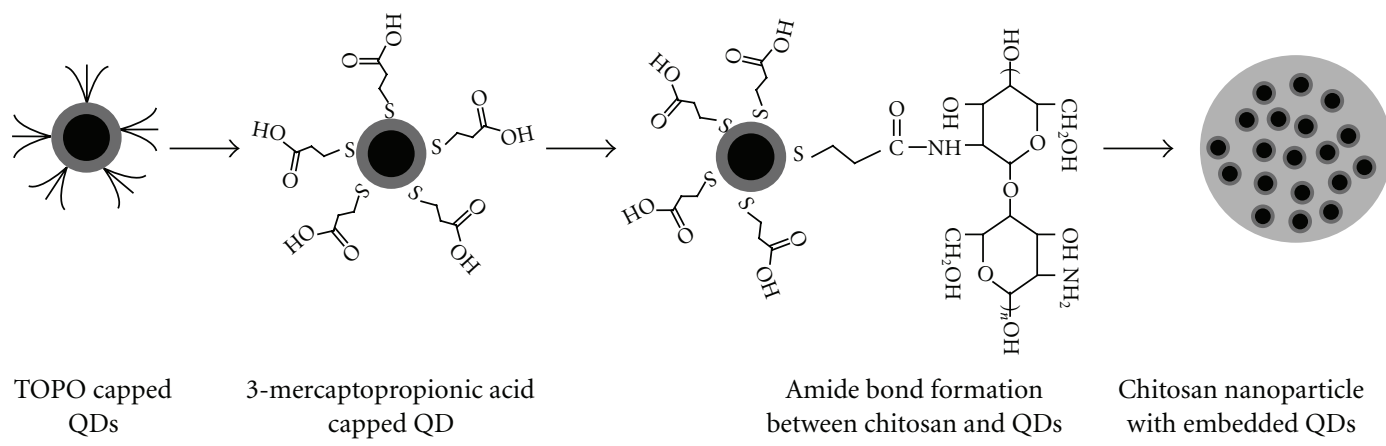

Figure 6: Schematic drawing to show the synthesis of chitosan nanoparticle embedded with QDs [84].

colour. A change in the concentration of proteins on each cell can be an early indication of cancer.

Therefore different molecular and cellular targets can be tagged with different colours. In this regard, due to band absorption profiles allowing simultaneous excitation of multiple colours, QD probes are attractive. The emission lengths can be tuned by varying the particle size and chemical composition.

\section{Synthesis of ZnS:Mn ${ }^{2+} / \mathrm{CdSe} / \mathrm{CdS}-\mathrm{CdTe}$ Quantum Dots}

4.1. Synthesis of ZnS:Mn ${ }^{2+}$ Quantum Dots. Zinc sulphide with low Mn doping level is an efficient phosphor (Toyama et al. 2000), used in the form of powder and thin films. In nanoparticle form, $\mathrm{ZnS}: \mathrm{Mn}^{2+}$ exhibits additional interesting electro-optical and other properties (Zeinert et al. 1994). There are various techniques for the preparation of $\mathrm{ZnS}: \mathrm{Mn}^{2+}$ nanoparticles, the two most popular ones being synthesis in colloidal solutions or in reverse micelles (Jin et al. 1996; Smith and Zhang 2000). The nanoparticles thus generated require capping by, for example, suitable thiols in order to avoid quick degradation or agglomeration. Another route may be synthesis in "controlled pore" solid materials like zeolites or rigid gels. Gels are interesting because their precursors, that is, sols, can easily be amenable to the formation of thin films. Confinement of the nanoparticles within the pores of rigid solid materials also hinders their degradation or agglomeration. Thin solid films with dispersed luminescent nanoparticles (as against colloidal dispersions) also have the advantage that they can be used readily as parts of optical (e.g., luminescent) devices. $\mathrm{ZnS}: \mathrm{Mn}^{2+}$ doped nanocrystals can be prepapred by various chemicals routes $[92,93]$.

4.2. Synthesis of CdS/CdSe Quantum Dots. An important landmark in the development of wet chemical routes for cadmium chalcogenide nanocrystals was, together with the nonaqueous TOP/TOPO technique, the use of different thiols as stabilizing agents in aqueous solution. A monodisperse size series of thioalcohol-stabilized CdS and CdTe nanoparticles with extremely small sizes ( $1-3 \mathrm{~nm}$ size range) was synthesized in aqueous solutions on the gram scale

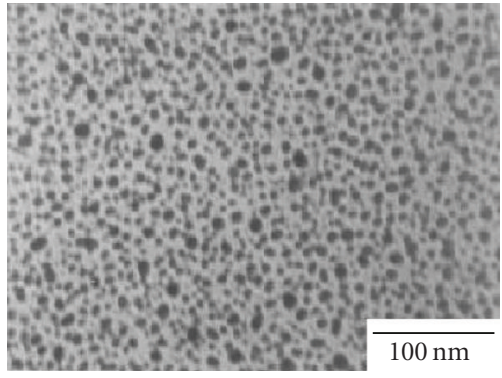

Figure 7: Transmission electron micrograph of a representative nanocrystalline $\mathrm{Mn}^{2+}$ doped (5 at.\%) ZnS film [92].

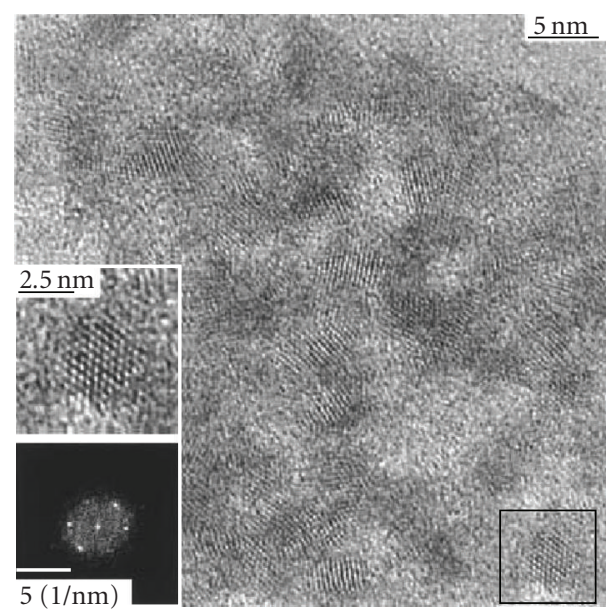

FIGURE 8: HRTEM overview image of thioglycerol-stabilized CdSe nanoparticles together with a single CdSe particle and its corresponding FFT (Fourier Transform) [94].

as redissolvable nanocrystalline powders or as crystals of nanoclusters (superstructures). To complete the series of thiolstabilized cadmium chalcogenide nanocrystals synthesized by a wet chemical route in aqueous solution, CdSe nanoparticles were synthesized [94].

The synthesis of monodisperse semiconductor nanocrystals, such as CdSe, CdS, or CdTe, can be achieved by injecting liquid precursors into hot $\left(300^{\circ} \mathrm{C}\right)$ coordinating organic solvent $[94,95]$. Adjusting the amount of precursors and 
crystal growth time generates QDs of specific sizes [9]. The quantum yield of the nanocrystal core synthesized as above is relatively low (less than 10\%) [2, 96]. Usually, a shell of high band-gap semiconductor material, such as $\mathrm{ZnS}$, is epitaxially grown around the core to achieve the quantum yield of up to $80 \%[95,96]$.

\section{Applications as Biosensors in Detection of Bacteria and Diagnosis of Diseases}

The use of quantum dots for sensitive and multicolor cellular imaging has seen major advances due to significant improvements in QD synthesis, surface chemistry and conjugation.

Some of the important applications are of quantum dots are as follow.

5.1. Labeling of Microorganisms. Biologically conjugated quantum dots (QDs) have shown great promise as multiwavelength fluorescent labels for on-chip bioassays and eukaryotic cells. However, use of these photoluminescent nanocrystals in bacteria has not previously been reported, and their large size ( 3 to $10 \mathrm{~nm}$ ) makes it unclear whether they inhibit bacterial recognition of attached molecules and whether they are able to pass through bacterial cell walls. The conjugated CdSe QDs were used for strain and metabolism-specific microbial labeling for a wide variety of bacteria and fungi. While cell surface molecules, such as glycoproteins, make excellent targets for conjugated QDs, internal labeling is inconsistent and leads to large spectral shifts compared with the original fluorescence, suggesting that there is breakup or dissolution of the QDs. Transmission electron microscopy of whole mounts and thin sections confirmed that bacteria are able to extract $\mathrm{Cd}$ and Se from QDs in a fashion dependent upon the QD surface conjugate [67].

5.2. Detection of Biofilms. The study of microorganisms at the aqueous/substratum interface is of great interest because bacterial attachment to surfaces is often associated with surface deterioration and corrosion. Extracellular polymeric substances anchor bacteria to the substrate [66] and serve as a survival mechanism in diverse environments including water distribution systems [97]. Decontamination of biofilms by dynamic changes in fluid shear resulting in biofilm deformation and detachment may be a viable alternative to chemical disinfection methods, however, detachment mechanisms have yet to be elucidated. QDs with two different surface chemistries (amine and carboxyl modified) were utilized to measure solute mobility and diffusion in bacterial cells and biofilms as a function of fluid shear. Bulk surface chemistry measurements were used to predict the governing interfacial interactions between QDs and bacterial cells/biofilms upon initial contact. Interaction energies of QDs with bacterial biofilms, governed by interfacial forces include van der Waals, electrostatics, and hydrophobicity (including Lewis acid/base contributions), are predicted to be largely attractive for bacterial and drinking water biofilms grown on PVC pipe. Diffusion coefficients for QDs in single (Pseudomonas

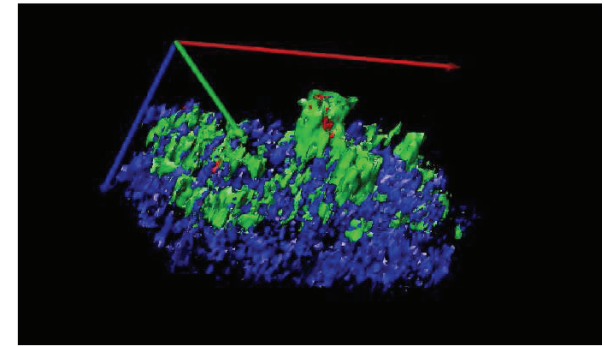

FIGURE 9: 3D reconstruction of laser scanning confocal microscopy image of biofilm sample. Green represents the green fluorescence protein (GFP) of Pseudomonas aeruginosa, red represents carboxylated QDs $(\mathrm{em}=655 \mathrm{~nm}$ ) and blue represents fluorescent labeled lectin which recognizes fucose (a polysaccharide common in biofilms). Note that the QDs appear to be most closely associated with bacterial surfaces and not fucose.

aeruginosa PAO1 and MCF-7 breast cancer cells) and native drinking water bacterial biofilms were dependent on the size and chemistry of the QDs and, in general, agreed well with predicted attractive interaction energies. However, uptake of QDs by cells was not observed and was attributed to significant aggregation at or near the cell surfaces (Figure 9).

5.3. Drug Delivery. QDs have also been investigated for use in drug delivery. Lai et al. used surface modified CdS QDs as chemically removable caps to keep pharmaceutical drug molecules and neurotransmitters inside a mesoporous silica nanosphere-based system. The CdS cap ensures the drug is inside the system until triggered by disulfide bond-reducing reagents. It is interesting to note that QDs here play a role as a size-defined cap and not as a fluorescent molecule.

5.4. Detection of Myocardial Infarction. Rapid, sensitive detection of blood borne Troponin I is extremely important for early detection of myocardial infarction. An optical biosensor has been proposed as a versatile, adaptable, and effective method for detection of Troponin I. The biosensor architecture utilizes fluorescence resonance energy transfer (FRET). In order to launch FRET, a donor-labeled Protein A molecule is bound to an acceptor-labeled capture antibody. When exposed to the Troponin I antigen, the antibodyantigen binding event initiates a conformational change within the structure of the antibody. As this morphological change in the antibody takes place, the distance between the donor and acceptor changes, resulting in a measurable shift in energy transfer. QDs were utilized as the FRET donors to further increase the efficiency of the biosensor system and organic dyes were utilized as the acceptors. This biosensor demonstrated an ample sensitivity to the analyze, achieving a lower limit of detection of approximately $32 \mathrm{nM}$ in phosphate buffered saline and $55 \mathrm{nM}$ in human plasma. A high degree of specificity was also observed when the response to cardiac Troponin I is compared with that of a nonspecific protein. Response time of the biosensor was determined to be less than $1 \mathrm{~min}$; an expeditious time compared with other Troponin diagnostic assays [87]. 


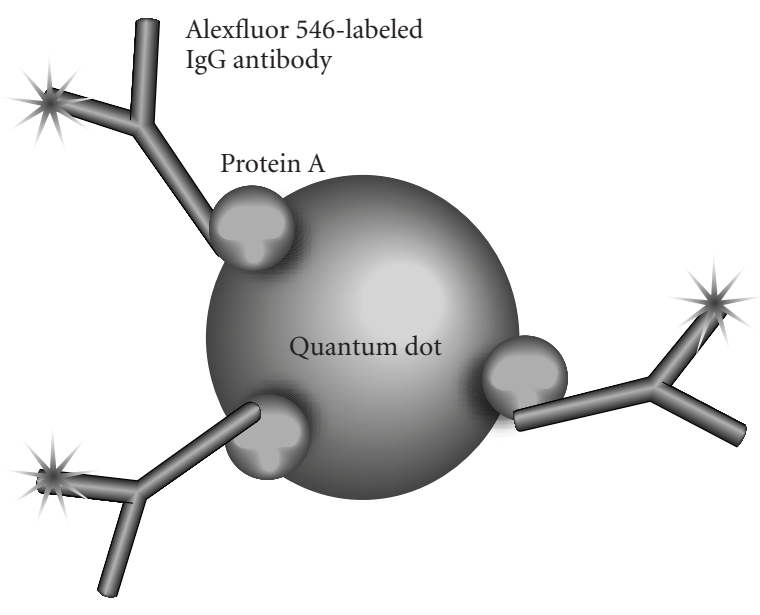

Figure 10: Schematic of self-assembled optical biosensor architecture.

5.5. Treatment of AIDs. QDs (zinc-sulfide-capped cadmium selenide) were used to label trichosanthin, and the absorption and fluorescent spectra and enzymatic activity of quantum dot-labeled trichosanthin (QD-TCS) were studied. The distribution of quantum dot-labeled trichosanthin within human choriocarcinoma cells for treatment of AIDs was also observed with two-photon laser scanning microscopy [85].

5.6. Labeling of Breast Cancer. For in vivo detection, clinical values of QDs as immunofluorescent probes require them to have high sensitivity and high specificity for cancer cells. QDs linked to immunoglobulin G IgG and streptavidin were studied and used to label the breast cancer marker Her2 on the surface of fixed and live cancer cells (refer Figure 10), which showed that QD probes can be very effective in cellular imaging and offer substantial advantages over organic dyes.

5.7. Tumor Targeting and Imaging. In another study, QDs were first used as stable fluorescent tracers for nonspecific uptake studies and lymph node mapping in living animals. In an important improvement, PEG-coated QDs were functionalized with antibodies to prostate-specific membrane antigen and were intravenously injected in mice for tumor targeting and imaging.

Most recently, self-illuminating quantum dot was conjugated as new probes for in vivo imaging. Specific immunofluorescent probes were synthesized by linking QDs to alphafetoprotein AFP antibody for specific recognization of AFP, an important marker for hepatocarcinoma cell line HCCLM6. In vivo, active tumor targeting and sensitive spectroscopic hepatoma imaging was achieved with an integrated fluorescence imaging system. The inhomogeneous distribution of the QD probes in tumor by using a sitebysite measurement method was investigated to test their ability for distribution studies of cancer cells in tumor. These results demonstrate the potential of QD probes as attractive immunofluorescent probes for cancer detection (Refer Figure 11, [68]).

Localization of specific biomolecules in cells and tissues at a high resolution provides both structural and quantitative information for molecular cell biology. However, popular immunofluorescence labeling is limited in spatial resolution. Because QDs are composed of heavy elements such as cadmium, it is possible to use them as contrast or labeling probes in transmission electron and X-ray microscopy for highresolution imaging of cells. Nisman et al. used CdSe QDs as probes in both conventional and energy-filtered TEM, demonstrating the feasibility of sample aggregation within cells and optimizing imaging and detection conditions for single QD experiments will be the key to achieve this goal.

\section{Toxic Effects of Quantum Dots}

QDs made up of cadmium (from cadmium chalcogenidebased quantum dots) or lead (from lead chalcogenide-based quantum dots) contain toxic components. According to Derfus et al. CdSe QDs are highly toxic to cultured cells under UV illumination for prolonged time. This is due to the energy of the UV irradiation that is close to the chemical bond and dissolves the semiconductor particles in a process called photolysis, which release toxic cadmium ions into the culture medium. Such cadmium and lead ions released from the QDs can cause immense harm to cells [98-100]. Thus a direct way to avoid the possible toxicity of QDs is to make them well coated to become biologically inert. The coating materials can be low or nontoxic organic molecules/polymers (e.g., PEG) or inorganic layers (e.g., $\mathrm{ZnS}$ and silica). Research shows, extracellular cytotoxicity of water-soluble CdSe and CdSe/ZnS QDs, because $\mathrm{Cd}^{2+}$ is released from the nanoparticles which is mostly due to poor purifications or incomplete surface cappings/coatings [52, 101]. QDs are encapsulated by simple molecules, such as mercaptoacetic acid, mercaptopropionic acid, 11mercaptoundecanoic acid, 2-aminoethanethiol, are more toxic than the ones coated with silica. The silica layer is different from the amphiphilic polymer layer or small molecular ligands; it can be very thick (up to several micrometers) and therefore reduces the possible leaking of interior toxic cadmium or lead under physiological conditions. There is no clear toxic effect observed if additional PEG molecules were attached to the silica exterior surface $[52,101,102]$. Chang et al. have found that QDs could enter the cells through endocytosis, and the cell death was highly related to the uptake quantity regardless of the surface coating [103]. Nonetheless, the surface coating did affect the uptake quantity and in turn influenced the intracellular cytotoxicity [23].

In fact, many biomedical imaging and detection applications of QDs encapsulated by complex molecules do not exhibit noticeable toxic effects [104]. One report states that the tumor cells labeled with QDs survived in circulation and extravasated into tissues just as effectively as unlabeled cells; there was no obvious difference in their ability to form tumors in mice after 40 days; and QDs had no adverse effects on the physiology of the host animal or labeled cells [105]. Another study also disclosed that water-soluble quantum dots encapsulated by amphiphilic polymers (with PEG) had very low toxicity to cells if the dosing level was lower than $100 \mathrm{nM}$ [106]. 
(a)

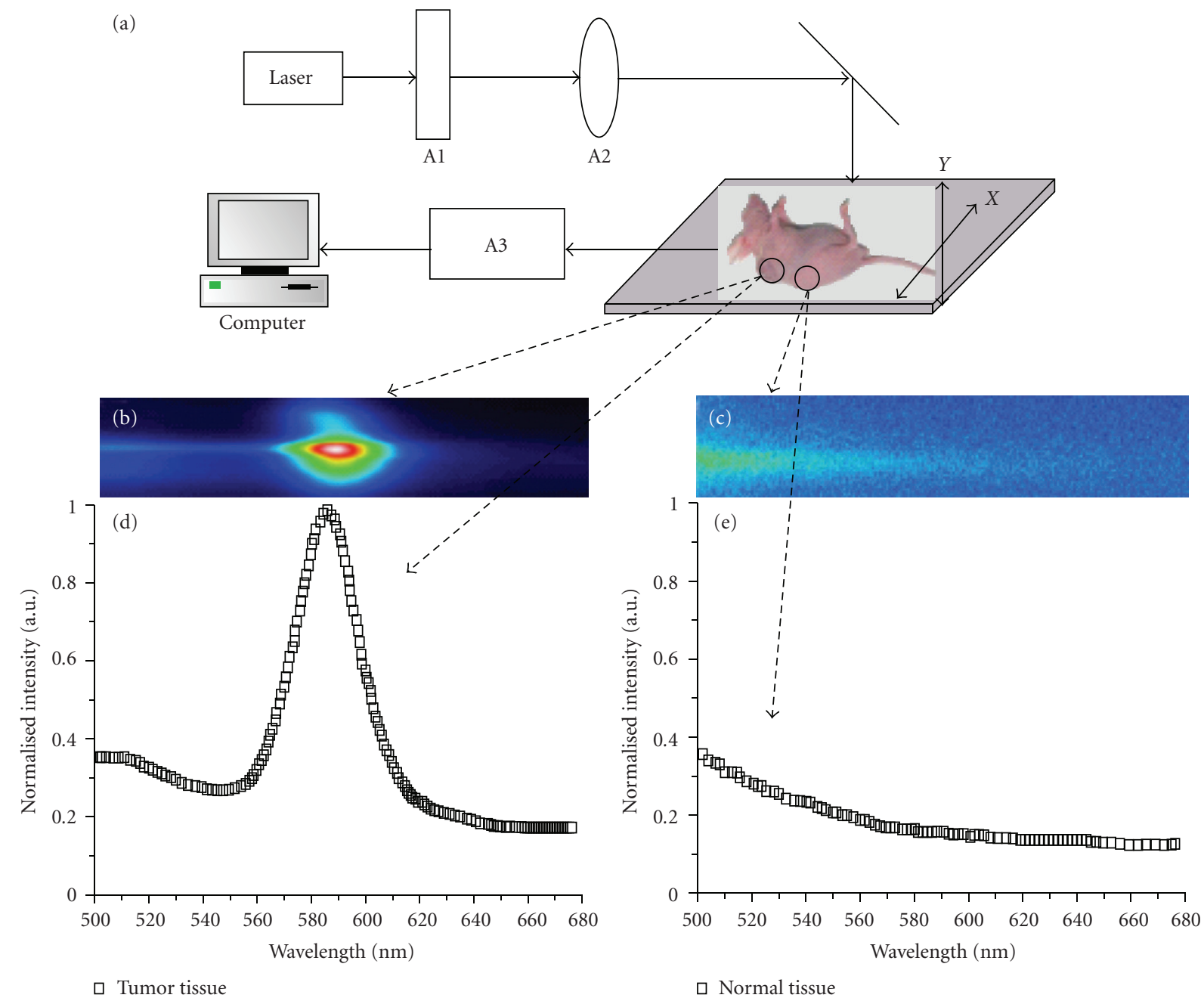

FIGURE 11: A Simple optical layout of fluorescence imaging system: (a1), optical frequency double system; (a2), lens; (a3), liquid-nitrogen cooled CCD-array spectrophotometer. (b) and (c) Spectroscopic imaging of (b) QDs-tagged tumor tissue and (c) normal tissue. (d) and (e) Emission spectrum of (d) QDs-tagged tumor tissue and (e) normal tissue. All the images and the spectrums were captured from a nude mouse with the same exposure time [68].

Though a lot of stable and robust coating strategies were developed in order to minimize the toxicity of current available QDs (stabilizing QD particles against bleaching, reducing cell uptake), a lot of effort was put to develop new high-quality quantum dot systems that do not contain very toxic components. Peng and his colleagues have synthesized $\mathrm{Cu}$ - or Mn- doped $\mathrm{ZnSe}$ quantum dots which emitted 470 $600 \mathrm{~nm}$ lights with relatively narrow FWHM $(45-65 \mathrm{~nm})$ and acceptable quantum efficiency (10-30\%) [107]. This will ultimately eliminate the extracellular and intracellular cytotoxicity of QDs from the toxic components.

However, QDs toxicity may also come from their native properties no matter what components or coating strategies used. QDs can transfer absorbed optical energy to nearby oxygen molecules to generate reactive oxygen species (ROS) such as free radicals (hydroxyl radical $(\mathrm{OH})$ and superoxide $\left(\mathrm{O}_{2}{ }^{-}\right)$and singlet oxygen $\left({ }^{1} \mathrm{O}_{2}\right)$, and then result in cell damage and death. Reactive oxygen species have been found in several QD systems, such as CdS, CdSe, CdSe/ZnS [58], and CdTe [108]. These reactive oxygen species on the contrary make quantum dots possible probes for photodynamic therapy (PDT) applications [109, 110]. DNA nicking by free radicals generated from CdSe and CdSe/ZnS quantum dots has been reported even under dark conditions [111]. QDs have been found accumulated in mouse bone marrow, spleen, and liver for at least four months after administration [86]. Particles larger than $50 \mathrm{~nm}$ could not be easily cleared from kidney; and the typically negative charged QDs may further reduce their clearance size from kidney [112]. Large and stable nanoparticles may be cleared from animal and human bodies through liver [113-116].

\section{Conclusion}

The unique properties of the QDs have already fulfilled their promises in the burgeoning new fields of Nanobiotechnology and Nanomedicine. Because of the tremendous efforts to improve the biological properties of the nanoparticles by 
polymer encapsulation, water solubility, aggregation, and biodistribution, promising breakthroughs have been made in the biological detection and application of nanoparticles in multifunctional nanostructures and nanodevices. The correlation between MRI and ultrasensitive optical imaging can help to visually identify tiny tumors or other small lesions during an operation and remove the diseased cells and tissue completely. Medical imaging modalities can identify the disease but do not provide a visual guide during surgery. The developement of magnetic or radioactive QD probes could solve this problem. $\mathrm{Fe}_{2} \mathrm{O}_{3}$ and $\mathrm{FePt}$ nanoparticles and paramagnetic gadolinium chelates are attached to QDs to use them as multimodality imaging probes.

QDs can be multimodelled in order to treat disease tissue and monitor them in real time. They have been shown to have potential activity as photodynamic therapy agents [109]. In order to realize the practical applications of these multifunctional QDs, careful research will be necessary. However the positive results obtained so far has shown success of QDs in biological systems and different biomedical applications.

\section{Future Prediction}

The fate of quantum dots in the field of biology can be predicted as follows.

(1) Multiple functional groups can be attached to a single QDs at the same time.

(2) Quantum efficiency of that QD will be increased.

(3) Sensitivity of QDs should be increased for better targeting such as drug delivery.

\section{References}

[1] A. I. Ekimov and A. A. Onushchenko, "Quantum size effects in the optical spectra of semiconductor micro-crystals," Soviet Physics of Semiconductors, vol. 16, pp. 775-778, 1982.

[2] C. B. Murray, D. J. Norris, and M. G. Bawendi, "Synthesis and characterization of nearly monodisperse $\mathrm{CdE}(\mathrm{E}=\mathrm{S}$, Se, $\mathrm{Te}$ ) semiconductor nanocrystallites," Journal of the American Chemical Society, vol. 115, no. 19, pp. 8706-8715, 1993.

[3] W. C. W. Chan and S. Nie, "Quantum dot bioconjugates for ultrasensitive nonisotopic detection," Science, vol. 281, no. 5385, pp. 2016-2018, 1998.

[4] M. Bruchez Jr., M. Moronne, P. Gin, S. Weiss, and A. P. Alivisatos, "Semiconductor nanocrystals as fluorescent biological labels," Science, vol. 281, no. 5385, pp. 2013-2016, 1998.

[5] T. Pellegrino, L. Manna, S. Kudera, et al., "Hydrophobic nanocrystals coated with an amphiphilic polymer shell: a general route to water soluble nanocrystals," Nano Letters, vol. 4, no. 4, pp. 703-707, 2004.

[6] W. Liu, M. Howarth, A. B. Greytak, et al., "Compact biocompatible quantum dots functionalized for cellular imaging," Journal of the American Chemical Society, vol. 130, no. 4, pp. 1274-1284, 2008.

[7] E. R. Goldman, E. D. Balighian, H. Mattoussi, et al., "Avidin: a natural bridge for quantum dot-antibody conjugates," Journal of the American Chemical Society, vol. 124, no. 22, pp. 6378-6382, 2002.
[8] M. E. Åkerman, W. C. W. Chan, P. Laakkonen, S. N. Bhatia, and E. Ruoslahti, "Nanocrystal targeting in vivo," Proceedings of the National Academy of Sciences of the United States of America, vol. 99, no. 20, pp. 12617-12621, 2002.

[9] R. Mahtab, J. P. Rogers, and C. J. Murphy, "Proteinsized quantum dot luminescence can distinguish between "straight", "bent", and "kinked" oligonucleotides," Journal of the American Chemical Society, vol. 117, no. 35, pp. 90999100, 1995.

[10] F. Osaki, T. Kanamori, S. Sando, T. Sera, and Y. Aoyama, "A quantum dot conjugated sugar ball and its cellular uptake. On the size effects of endocytosis in the subviral region," Journal of the American Chemical Society, vol. 126, no. 21, pp. 6520-6521, 2004.

[11] Y. Chen, T. Ji, and Z. Rosenzweig, "Synthesis of glyconanospheres containing luminescent CdSe-ZnS quantum dots," Nano Letters, vol. 3, no. 5, pp. 581-584, 2003.

[12] B. M. Lingerfelt, H. Mattoussi, E. R. Goldman, J. M. Mauro, and G. P. Anderson, "Preparation of quantum dot-biotin conjugates and their use in immunochromatography assays," Analytical Chemistry, vol. 75, no. 16, pp. 4043-4049, 2003.

[13] R. P. Haugland, The Handbook: A Guide to Fluorescent Probes and Labeling Technologies, Invitrogen, San Diego, Calif, USA, 10th edition, 2005.

[14] J. R. Lakowicz, Principles of Fluorescence Spectroscopy, Kluwer Academic/Plenum Publishers, New York, NY, USA, 2nd edition, 1999.

[15] M. Dahan, S. Lévi, C. Luccardini, P. Rostaing, B. Riveau, and A. Triller, "Diffusion dynamics of glycine receptors revealed by single-quantum dot tracking," Science, vol. 302, no. 5644, pp. 442-445, 2003.

[16] X. Gao, Y. Cui, R. M. Levenson, L. W. K. Chung, and S. Nie, "In vivo cancer targeting and imaging with semiconductor quantum dots," Nature Biotechnology, vol. 22, no. 8, pp. 969976, 2004.

[17] B. N. G. Giepmans, S. R. Adams, M. H. Ellisman, and R. Y. Tsien, "The fluorescent toolbox for assessing protein location and function," Science, vol. 312, no. 5771, pp. 217-224, 2006.

[18] M. Bruchez Jr., M. Moronne, P. Gin, S. Weiss, and A. P. Alivisatos, "Semiconductor nanocrystals as fluorescent biological labels," Science, vol. 281, no. 5385, pp. 2013-2016, 1998.

[19] L. J. Kricka, "Stains, labels and detection strategies for nucleic acids assays," Annals of Clinical Biochemistry, vol. 39, no. 2, pp. 114-129, 2002.

[20] I. L. Medintz, H. T. Uyeda, E. R. Goldman, and H. Mattoussi, "Quantum dot bioconjugates for imaging, labelling and sensing," Nature Materials, vol. 4, no. 6, pp. 435-446, 2005.

[21] X. Michalet, F. F. Pinaud, L. A. Bentolila, et al., "Quantum dots for live cells, in vivo imaging, and diagnostics," Science, vol. 307, no. 5709, pp. 538-544, 2005.

[22] A. Fu, W. Gu, B. Boussert, et al., "Semiconductor quantum rods as single molecule fluorescent biological labels," Nano Letters, vol. 7, no. 1, pp. 179-182, 2007.

[23] A. P. Alivisatos, W. Gu, and C. Larabell, "Quantum dots as cellular probes," Annual Review of Biomedical Engineering, vol. 7, pp. 55-76, 2005.

[24] W. J. Parak, T. Pellegrino, and C. Plank, "Labelling of cells with quantum dots," Nanotechnology, vol. 16, no. 2, pp. R9R25, 2005.

[25] W. J. Parak, R. Boudreau, M. Le Gros, et al., "Cell motility and metastatic potential studies based on quantum dot imaging of phagokinetic tracks," Advanced Materials, vol. 14, no. 12, pp. 882-885, 2002. 
[26] W. J. Parak, D. Gerion, T. Pellegrino, et al., "Biological applications of colloidal nanocrystals," Nanotechnology, vol. 14, no. 7, pp. R15-R27, 2003.

[27] K. E. Sapsford, T. Pons, I. L. Medintz, and H. Mattoussi, "Biosensing with luminescent semiconductor quantum dots," Sensors, vol. 6, no. 8, pp. 925-953, 2006.

[28] M. Ozkan, "Quantum dots and other nanoparticles: what can they offer to drug discovery?" Drug Discovery Today, vol. 9, no. 24, pp. 1065-1071, 2004.

[29] C. J. Murphy, "Optical sensing with quantum dots," Analytical Chemistry, vol. 74, no. 19, pp. 520A-526A, 2002.

[30] X. Peng, M. C. Schlamp, A. V. Kadavanich, and A. P. Alivisatos, "Epitaxial growth of highly luminescent CdSe/CdS core/shell nanocrystals with photostability and electronic accessibility," Journal of the American Chemical Society, vol. 119, no. 30, pp. 7019-7029, 1997.

[31] C. B. Murray, C. R. Kagan, and M. G. Bawendi, "Synthesis and characterization of monodisperse nanocrystals and close-packed nanocrystal assemblies," Annual Review of Materials Science, vol. 30, pp. 545-610, 2000.

[32] A. M. Derfus, W. C. W. Chan, and S. N. Bhatia, "Probing the cytotoxicity of semiconductor quantum dots," Nano Letters, vol. 4, no. 1, pp. 11-18, 2004.

[33] W. Liu, M. Howarth, A. B. Greytak, et al., "Compact biocompatible quantum dots functionalized for cellular imaging," Journal of the American Chemical Society, vol. 130, no. 4, pp. 1274-1284, 2008.

[34] R. A. Brooks, F. Moiny, and P. Gillis, "On $T_{2}$-shortening by weakly magnetized particles: the chemical exchange model," Magnetic Resonance in Medicine, vol. 45, no. 6, pp. 10141020, 2001.

[35] N. Nitin, L. E. W. LaConte, O. Zurkiya, X. Hu, and G. Bao, "Functionalization and peptide-based delivery of magnetic nanoparticles as an intracellular MRI contrast agent," Journal of Biological Inorganic Chemistry, vol. 9, no. 6, pp. 706-712, 2004.

[36] S. Palmacci and L. Josephson, "Synthesis of polysaccharide covered superparamagnetic oxide colloids," U.S. patent, no. 5262176, 1993.

[37] M. Zhou, E. Nakatani, L. S. Gronenberg, et al., "Peptidelabeled quantum dots for imaging GPCRs in whole cells and as single molecules," Bioconjugate Chemistry, vol. 18, no. 2, pp. 323-332, 2007.

[38] C. Y. Zhang, H. Ma, S. M. Nie, Y. Ding, L. Jin, and D. Y. Chen, "Quantum dot-labeled trichosanthin," Analyst, vol. 125, no. 6, pp. 1029-1031, 2000.

[39] J. O. Winter, T. Y. Liu, B. A. Korgel, and C. E. Schmidt, "Recognition molecule directed interfacing between semiconductor quantum dots and nerve cells," Advanced Materials, vol. 13, no. 22, pp. 1673-1677, 2001.

[40] J. A. Kloepfer, R. E. Mielke, M. S. Wong, K. H. Nealson, G. Stucky, and J. L. Nadeau, "Quantum dots as strainand metabolism-specific microbiological labels," Applied and Environmental Microbiology, vol. 69, no. 7, pp. 4205-4213, 2003.

[41] G. P. Mitchell, C. A. Mirkin, and R. L. Letsinger, "Programmed assembly of DNA functionalized quantum dots," Journal of the American Chemical Society, vol. 121, no. 35, pp. 8122-8123, 1999.

[42] K.-I. Hanaki, A. Momo, T. Oku, et al., "Semiconductor quantum dot/albumin complex is a long-life and highly photostable endosome marker," Biochemical and Biophysical Research Communications, vol. 302, no. 3, pp. 496-501, 2003.
[43] C.-C. Chen, C.-P. Yet, H.-N. Wang, and C.-Y. Chao, "Selfassembly of monolayers of cadmium selenide nanocrystals with dual color emission," Langmuir, vol. 15, no. 20, pp. 6845-6850, 1999.

[44] J. K. Jaiswal, H. Mattoussi, J. M. Mauro, and S. M. Simon, "Long-term multiple color imaging of live cells using quantum dot bioconjugates," Nature Biotechnology, vol. 21, no. 1, pp. 47-51, 2003.

[45] A. Sukhanova, L. Venteo, J. Devy, et al., "Highly stable fluorescent nanocrystals as a novel class of labels for immunohistochemical analysis of paraffin-embedded tissue sections," Laboratory Investigation, vol. 82, no. 9, pp. 12591261, 2002.

[46] A. Sukhanova, J. Devy, L. Venteo, et al., "Biocompatible fluorescent nanocrystals for immunolabeling of membrane proteins and cells," Analytical Biochemistry, vol. 324, no. 1, pp. 60-67, 2004.

[47] F. Pinaud, D. King, H.-P. Moore, and S. Weiss, "Bioactivation and cell targeting of semiconductor CdSe/ZnS nanocrystals with phytochelatin-related peptides," Journal of the American Chemical Society, vol. 126, no. 19, pp. 6115-6123, 2004.

[48] S. Pathak, S.-K. Choi, N. Arnheim, and M. E. Thompson, "Hydroxylated quantum dots as luminescent probes for in situ hybridization," Journal of the American Chemical Society, vol. 123, no. 17, pp. 4103-4104, 2001.

[49] Y. A. Wang, J. J. Li, H. Chen, and X. Peng, "Stabilization of inorganic nanocrystals by organic dendrons," Journal of the American Chemical Society, vol. 124, no. 10, pp. 2293-2298, 2002.

[50] H. Skaff and T. Emrick, "The use of 4-substituted pyridines to afford amphiphilic, pegylated cadmium selenide nanoparticles," Chemical Communications, vol. 9, no. 1, pp. 52-53, 2003.

[51] M. Giersig, L. M. Liz-Marzán, T. Ung, D. Su, and P. Mulvaney, "Chemistry of nanosized silica-coated metal particles-EMstudy," Physical Chemistry, vol. 101, no. 11, pp. 1617-1620, 1997.

[52] M. A. Correa-Duarte, M. Giersig, and L. M. Liz-Marzán, "Stabilization of CdS semiconductor nanoparticles against photodegradation by a silica coating procedure," Chemical Physics Letters, vol. 286, no. 5-6, pp. 497-501, 1998.

[53] P. Mulvaney, L. M. Liz-Marzán, M. Giersig, and T. Ung, "Silica encapsulation of quantum dots and metal clusters," Journal of Materials Chemistry, vol. 10, no. 6, pp. 1259-1270, 2000.

[54] A. Schroedter, H. Weller, R. Eritja, W. E. Ford, and J. M. Wessels, "Biofunctionalization of silica-coated CdTe and gold nanocrystals," Nano Letters, vol. 2, no. 12, pp. 1363-1367, 2002.

[55] W. C. W. Chan, D. J. Maxwell, X. Gao, R. E. Bailey, M. Han, and S. Nie, "Luminescent quantum dots for multiplexed biological detection and imaging," Current Opinion in Biotechnology, vol. 13, no. 1, pp. 40-46, 2002.

[56] M. E. Åkerman, W. C. W. Chan, P. Laakkonen, S. N. Bhatia, and E. Ruoslahti, "Nanocrystal targeting in vivo," Proceedings of the National Academy of Sciences of the United States of America, vol. 99, no. 20, pp. 12617-12621, 2002.

[57] S. J. Rosenthal, I. Tomlinson, E. M. Adkins, et al., "Targeting cell surface receptors with ligand-conjugated nanocrystals," Journal of the American Chemical Society, vol. 124, no. 17, pp. 4586-4594, 2002.

[58] H. Mattoussi, J. M. Mauro, E. R. Goldman, et al., "Bioconjugation of highly luminescent colloidal CdSe-ZnS quantum 
dots with an engineered two-domain recombinant protein," Physica Status Solidi B, vol. 224, no. 1, pp. 277-283, 2001.

[59] M. Aslam and A. Dent, Bioconjugation: Protein Coupling Techniques for the Biomedical Sciences, Grove's Dictionaries, New York, NY, USA; Macmillan, London, UK.

[60] J. O. Winter, T. Y. Liu, B. A. Korgel, and C. E. Schmidt, "Recognition molecule directed interfacing between semiconductor quantum dots and nerve cells," Advanced Materials, vol. 13, no. 22, pp. 1673-1677, 2001.

[61] W. Guo, J. J. Li, Y. A. Wang, and X. Peng, "Conjugation chemistry and bioapplications of semiconductor box nanocrystals prepared via dendrimer bridging," Chemistry of Materials, vol. 15, no. 16, pp. 3125-3133, 2003.

[62] X. Gao, W. C. W. Chan, and S. Nie, "Quantum-dot nanocrystals for ultrasensitive biological labeling and multicolor optical encoding," Journal of Biomedical Optics, vol. 7, no. 4, pp. 532-537, 2002.

[63] E. R. Goldman, G. P. Anderson, P. T. Tran, H. Mattoussi, P. T. Charles, and J. M. Mauro, "Conjugation of luminescent quantum dots with antibodies using an engineered adaptor protein to provide new reagents for fluoroimmunoassays," Analytical Chemistry, vol. 74, no. 4, pp. 841-847, 2002.

[64] G. T. Hermanson, Bioconjugate Techniques, Academic Press, San Diego, Calif, USA, 1st edition, 1996.

[65] E. R. Goldman, E. D. Balighian, H. Mattoussi, et al., "Avidin: a natural bridge for quantum dot-antibody conjugates," Journal of the American Chemical Society, vol. 124, no. 22, pp. 6378-6382, 2002.

[66] Alexandra Kroll, Mike H. Pillukat, Daniela Hahn, K. H. Nealson, and Jürgen Schnekenburger, "Current in vitro methods in nanoparticle risk assessment: Limitations and challenges," European Journal of Pharmaceutics and Biopharmaceutics, vol. 72, no. 2, pp. 370-377, 2009.

[67] J. A. Kloepfer, R. E. Mielke, and J. L. Nadeau, "Uptake of CdSe and CdSe/ZnS quantum dots into bacteria via purine-dependent mechanisms," Applied and Environmental Microbiology, vol. 71, no. 5, pp. 2548-2557, 2005.

[68] X. Yu, L. Chen, K. Li, et al., "Immunofluorescence detection with quantum dot bioconjugates for hepatoma in vivo," Journal of Biomedical Optics, vol. 12, no. 1, Article ID 014008, 2007.

[69] W. J. Jin, M.T. Fernández-Argüelles, J. M. Costa-Fernández, R. Pereiro, and A. Sanz-Medel, "Photoactivated luminescent CdSe quantum dots as sensitive cyanide probes in aqueous solutions," Chemical Communications, no. 7, pp. 883-885, 2005.

[70] Q. Ma, X. Wang, Y. Li, X. Su, and Q. Jin, "The use of CdTe quantum dot fluorescent microspheres in fluoroimmunoassays and a microfluidic chip system," Luminescence, vol. 22, no. 5, pp. 438-445, 2007.

[71] H. C. Warad, S. C. Ghosh, C. Thanachayanont, J. Dutta, and J. G. Hilborn, "Highly luminescent manganese doped ZnS quantum dots for biological labeling," in Proceedings of International Conference on Smart Materials/Intelligent Materials (SmartMat '04), pp. 203-206, Chiang Mai, Thailand, 2004.

[72] M. A. Hahn, J. S. Tabb, and T. D. Krauss, "Detection of single bacterial pathogens with semiconductor quantum dots," Analytical Chemistry, vol. 77, no. 15, pp. 4861-4869, 2005.

[73] B. S. Shah, P. A. Clark, E. K. Moioli, M. A. Stroscio, and J. J. Mao, "Labeling of mesenchymal stem cells by bioconjugated quantum dots," Nano Letters, vol. 7, no. 10, pp. 3071-3079, 2007.
[74] L. Y. Lee, S. L. Ong, J. Y. Hu, et al., "Use of semiconductor quantum dots for photostable immunofluorescence labeling of Cryptosporidium parvum," Applied and Environmental Microbiology, vol. 70, no. 10, pp. 5732-5736, 2004.

[75] A. Mansson, M. Sundberg, M. Balaz, et al., "In vitro sliding of actin filaments labelled with single quantum dots," Biochemical and Biophysical Research Communications, vol. 314, no. 2, pp. 529-534, 2004.

[76] Y. Xiao and P. E. Barker, "Semiconductor nanocrystal probes for human metaphase chromosomes," Nucleic Acids Research, vol. 32, no. 3, article e28, 2004.

[77] I. D. Tomlinson, J. N. Mason, R. D. Blakely, and S. J. Rosenthal, "Peptide-conjugated quantum dots: imaging the angiotensin type 1 receptor in living cells," Methods in Molecular Biology, vol. 303, pp. 51-60, 2005.

[78] Alfred J. Baca, Feimeng Zhou, Jun Wang, et al., "Attachment of Ferrocene-Capped Gold Nanoparticle/Streptavidin Conjugates onto Electrode Surfaces Covered with BiotinylatedBiomolecules for Enhanced Voltammetric Analysis," Electroanalysis, vol. 16, no. 1-2, 2004.

[79] C.-Y. Zhang and L. W. Johnson, "Homogenous rapid detection of nucleic acids using two-color quantum dots," Analyst, vol. 131, no. 4, pp. 484-488, 2006.

[80] W. Shi and X. Ma, "The detection application of CdS quantum dots in labeling DNA molecules," Biomedical Materials, vol. 1, no. 2, pp. 81-84, 2006.

[81] M. Zhou, E. Nakatani, L. S. Gronenberg, et al., "Peptidelabeled quantum dots for imaging GPCRs in whole cells and as single molecules," Bioconjugate Chemistry, vol. 18, no. 2, pp. 323-332, 2007.

[82] H. Peng, L. Zhang, T. H. M. Kjällman, C. Soeller, and J. Travas-Sejdic, "DNA hybridization detection with blue luminescent quantum dots and dye-labeled single-stranded DNA," Journal of the American Chemical Society, vol. 129, no. 11, pp. 3048-3049, 2007.

[83] L. Etgar, E. Lifshitz, and R. Tannenbaum, "Synthesis of water soluble PbSe quantum dots," in Materials Research Society Symposium Proceedings, vol. 959, pp. 172-177, Boston, Mass, USA, November 2007.

[84] Q. Nie, W. B. Tan, and Y. Zhang, "Synthesis and characterization of monodisperse chitosan nanoparticles with embedded quantum dots," Nanotechnology, vol. 17, no. 1, pp. 140-144, 2006.

[85] Andrew J. Sutherland, "Quantum dots as luminescent probes in biological systems," Current Opinion in Solid State and Materials Science, vol. 6, no. 4, pp. 365-370, 2002.

[86] B. Ballou, B. C. Lagerholm, L. A. Ernst, M. P. Bruchez, and A. S. Waggoner, "Noninvasive imaging of quantum dots in mice," Bioconjugate Chemistry, vol. 15, no. 1, pp. 79-86, 2004.

[87] C. M. Niemeyer, "Nanoparticles, proteins, and nucleic acids: biotechnology meets materials science," Angewandte Chemie International Edition, vol. 40, no. 22, pp. 4128-4158, 2001.

[88] J. W. Costerton, Z. Lewandowski, D. E. Caldwell, D. R. Korber, and H. M. Lappin-Scott, "Microbial biofilms," Annual Review of Microbiology, vol. 49, pp. 711-745, 1995.

[89] L. M. Demers, C. A. Mirkin, R. C. Mucic, et al., "A fluorescence-based method for determining the surface coverage and hybridization efficiency of thiol-capped oligonucleotides bound to gold thin films and nanoparticles," Analytical Chemistry, vol. 72, no. 22, pp. 5535-5541, 2000.

[90] K. E. Sapsford, T. Pons, I. L. Medintz, and H. Mattoussi, "Biosensing with luminescent semiconductor quantum dots," Sensors, vol. 6, no. 8, pp. 925-953, 2006. 
[91] C. A. Leatherdale, W.-K. Woo, F. V. Mikulec, and M. G. Bawendi, "On the absorption cross section of CdSe nanocrystal quantum dots," Journal of Physical Chemistry B, vol. 106, no. 31, pp. 7619-7622, 2002.

[92] B. Bhattacharjee, D. Ganguli, K. Iakoubovskii, A. Stesmans, and S. Chaudhuri, "Synthesis and characterization of solgel derived $\mathrm{ZnS}: \mathrm{Mn}^{2+}$ nanocrystallites embedded in a silica matrix," Bulletin of Materials Science, vol. 25, no. 3, pp. 175180, 2002.

[93] R. N. Bhargava, D. Gallagher, X. Hong, and A. Nurmikko, "Optical properties of manganese-doped nanocrystals of ZnS," Physical Review Letters, vol. 72, no. 3, pp. 416-419, 1994.

[94] A. L. Rogach, A. Kornowski, M. Gao, A. Eychmüller, and H. Weller, "Synthesis and characterization of a size series of extremely small thiol-stabilized CdSe nanocrystals," Journal of Physical Chemistry B, vol. 103, no. 16, pp. 3065-3069, 1999.

[95] M. A. Hines and P. Guyot-Sionnest, "Synthesis and characterization of strongly luminescing ZnS-capped CdSe nanocrystals," Journal of Physical Chemistry, vol. 100, no. 2, pp. 468471, 1996.

[96] X. Peng, M. C. Schlamp, A. V. Kadavanich, and A. P. Alivisatos, "Epitaxial growth of highly luminescent $\mathrm{CdSe} / \mathrm{CdS}$ core/shell nanocrystals with photostability and electronic accessibility," Journal of the American Chemical Society, vol. 119, no. 30, pp. 7019-7029, 1997.

[97] L. Hall-Stoodley, J. W. Costerton, and P. Stoodley, "Bacterial biofilms: from the natural environment to infectious diseases," Nature Reviews Microbiology, vol. 2, no. 2, pp. 95-108, 2004.

[98] A. Celik, U. Comelekoglu, and S. Yalin, "A study on the investigation of cadmium chloride genotoxicity in rat bone marrow using micronucleus test and chromosome aberration analysis," Toxicology and Industrial Health, vol. 21, no. 10, pp. 243-248, 2005.

[99] A. B. Fischer and Y. Skreb, "In vitro toxicology of heavy metals using mammalian cells: an overview of collaborative research data," Arhiv za Higijenu Rada i Toksikologiju, vol. 52, no. 3, pp. 333-354, 2001.

[100] C. Boudene and M. Damerval, "Cytotoxicity of mercury and cadmium," Toxicological European Research, vol. 4, no. 3, pp. 143-150, 1982.

[101] C. Kirchner, T. Liedl, S. Kudera, et al., "Cytotoxicity of colloidal CdSe and CdSe/ZnS nanoparticles," Nano Letters, vol. 5, no. 2, pp. 331-338, 2005.

[102] A. Hoshino, K. Fujioka, T. Oku, et al., "Physicochemical properties and cellular toxicity of nanocrystal quantum dots depend on their surface modification," Nano Letters, vol. 4, no. 11, pp. 2163-2169, 2004.

[103] E. Chang, N. Thekkek, W. W. Yu, V. L. Colvin, and R. Drezek, "Evaluation of quantum dot cytotoxicity based on intracellular uptake," Small, vol. 2, no. 12, pp. 1412-1417, 2006.

[104] A. Miyawaki, A. Sawano, and T. Kogure, "Lighting up cells: labelling proteins with fluorophores," Nature Cell Biology, vol. 5, supplement, pp. S1-S7, 2003.

[105] E. B. Voura, J. K. Jaiswal, H. Mattoussi, and S. M. Simon, "Tracking metastatic tumor cell extravasation with quantum dot nanocrystals and fluorescence emission-scanning microscopy," Nature Medicine, vol. 10, no. 9, pp. 993-998, 2004.

[106] E. Chang, W. W. Yu, V. L. Colvin, and R. Drezek, "Quantifying the influence of surface coatings on quantum dot uptake in cells," Journal of Biomedical Nanotechnology, vol. 1, no. 4, pp. 397-401, 2005.

[107] N. Pradhan, D. Goorskey, J. Thessing, and X. Peng, "An alternative of CdSe nanocrystal emitters: pure and tunable impurity emissions in ZnSe nanocrystals," Journal of the American Chemical Society, vol. 127, no. 50, pp. 1758617587, 2005.

[108] J. Lovrić, S. J. Cho, F. M. Winnik, and D. Maysinger, "Unmodified cadmium telluride quantum dots induce reactive oxygen species formation leading to multiple organelle damage and cell death," Chemistry and Biology, vol. 12, no. 11, pp. 1227-1234, 2005.

[109] A. C. S. Samia, X. Chen, and C. Burda, "Semiconductor quantum dots for photodynamic therapy," Journal of the American Chemical Society, vol. 125, no. 51, pp. 1573615737, 2003.

[110] R. Bakalova, H. Ohba, Z. Zhelev, et al., "Quantum dot antiCD conjugates: are they potential photosensitizers or potentiators of classical photosensitizing agents in photodynamic therapy of cancer?" Nano Letters, vol. 4, no. 9, pp. 1567-1573, 2004.

[111] M. Green and E. Howman, "Semiconductor quantum dots and free radical induced DNA nicking," Chemical Communications, no. 1, pp. 121-123, 2005.

[112] J. Patrakka, A.-T. Lahdenkari, O. Koskimies, C. Holmberg, J. Wartiovaara, and H. Jalanko, "The number of podocyte slit diaphragms is decreased in minimal change nephrotic syndrome," Pediatric Research, vol. 52, no. 3, pp. 349-355, 2002.

[113] S. Mornet, S. Vasseur, F. Grasset, and E. Duguet, "Magnetic nanoparticle design for medical diagnosis and therapy," Journal of Materials Chemistry, vol. 14, no. 14, pp. 2161-2175, 2004.

[114] S. M. Moghimi, A. C. Hunter, and J. C. Murray, "Longcirculating and target-specific nanoparticles: theory to practice," Pharmacological Reviews, vol. 53, no. 2, pp. 283-318, 2001.

[115] S. M. Moghimi and H. M. Patel, "Serum-mediated recognition of liposomes by phagocytic cells of the reticuloendothelial system: the concept of tissue specificity," Advanced Drug Delivery Reviews, vol. 32, no. 1-2, pp. 45-60, 1998.

[116] S. J. Douglas, S. S. Davis, and L. Illum, "Nanoparticles in drug delivery," Critical Reviews in Therapeutic Drug Carrier Systems, vol. 3, no. 3, pp. 233-261, 1987. 

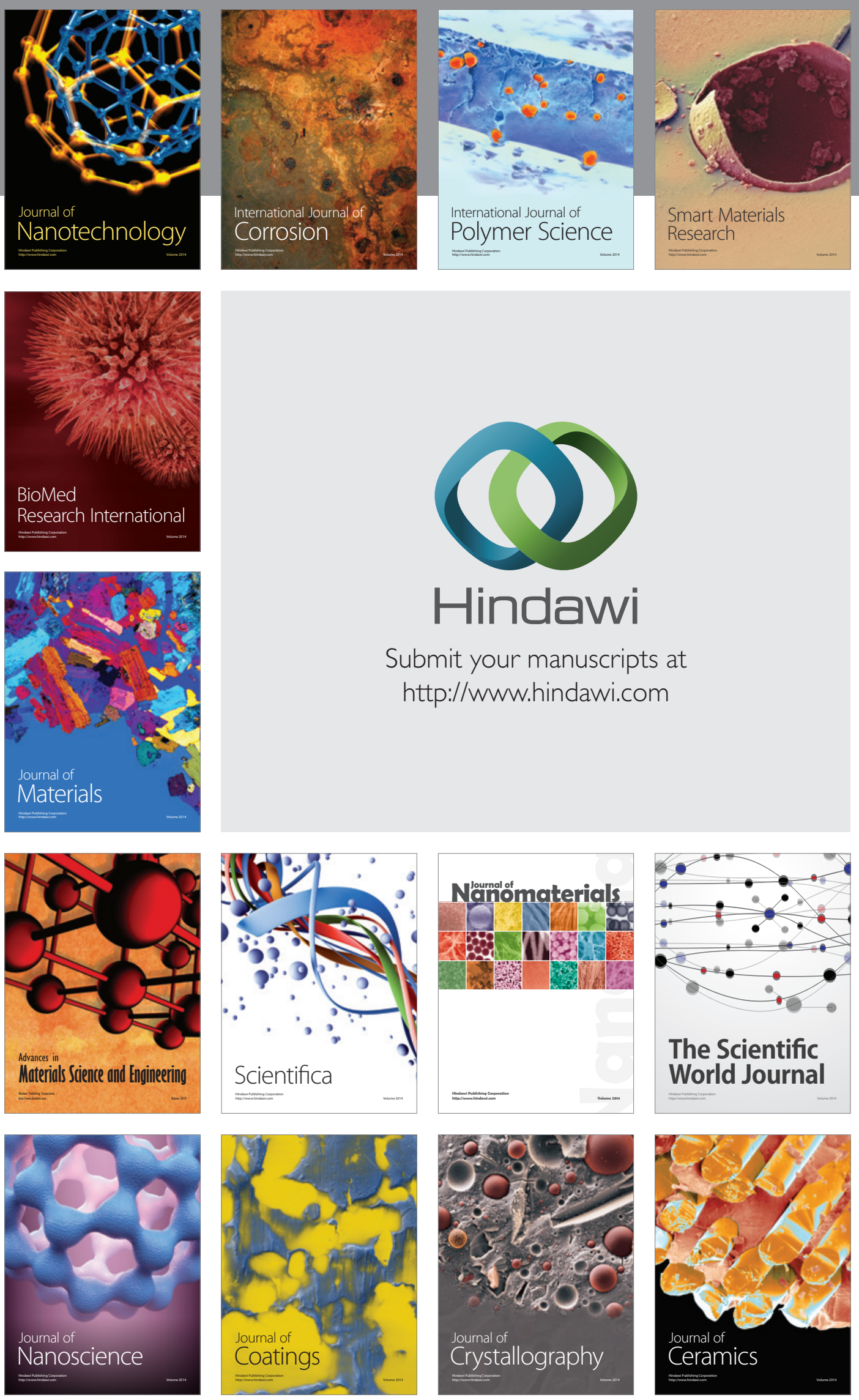

The Scientific World Journal

Submit your manuscripts at

http://www.hindawi.com

\section{World Journal}

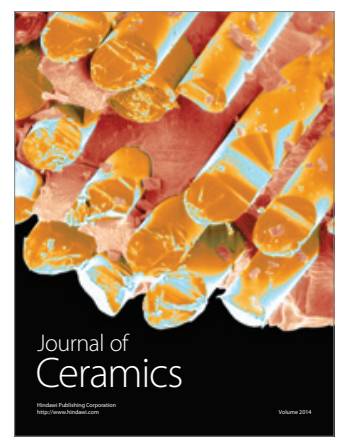

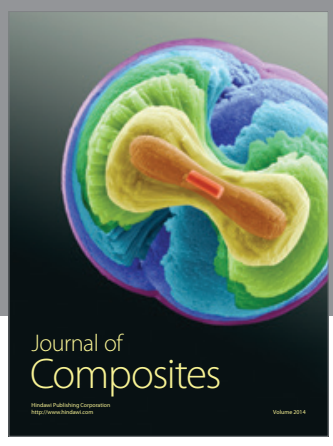
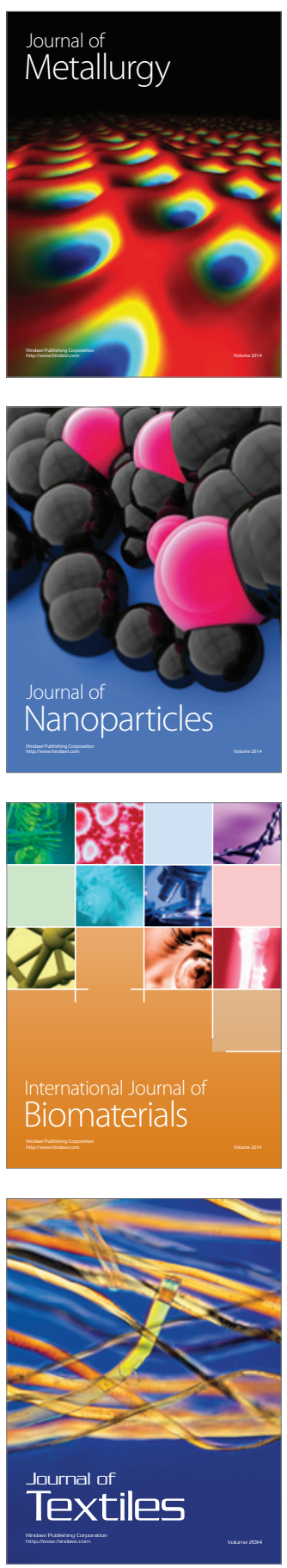